\title{
Comparison of total water vapour content in the Arctic derived from GNSS, AIRS, MODIS and SCIAMACHY
}

\author{
Dunya Alraddawi $^{1}$, Alain Sarkissian ${ }^{1}$, Philippe Keckhut $^{1}$, Olivier Bock $^{2}$, Stefan Noël ${ }^{3}$, Slimane Bekki $^{1}$, \\ Abdenour Irbah ${ }^{1}$, Mustapha Meftah ${ }^{1}$, and Chantal Claud ${ }^{1,4}$ \\ ${ }^{1}$ OVSQ-LATMOS, University of Paris-Saclay, Guyancourt 78280, France \\ ${ }^{2}$ IGN-LAREG, University of Paris-Diderot, Paris 75013, France \\ ${ }^{3}$ Institute of Environmental Physics, University of Bremen, 28334 Bremen, Germany \\ ${ }^{4}$ LMD/IPSL, CNRS, École Polytechnique, University of Paris-Saclay, ENS, PSL Research University, Sorbonne Universités, \\ UPMC Univ. Paris 06, Palaiseau, France
}

Correspondence: Alain Sarkissian (alain.sarkissian@latmos.ipsl.fr)

Received: 3 July 2017 - Discussion started: 28 July 2017

Revised: 7 April 2018 - Accepted: 16 April 2018 - Published: 18 May 2018

\begin{abstract}
Atmospheric water vapour plays a key role in the Arctic radiation budget, hydrological cycle and hence climate, but its measurement with high accuracy remains an important challenge. Total column water vapour (TCWV) datasets derived from ground-based GNSS measurements are used to assess the quality of different existing satellite TCWV datasets, namely from the Moderate Resolution Imaging Spectroradiometer (MODIS), the Atmospheric Infrared Sounder (AIRS) and the SCanning Imaging Absorption spectroMeter for Atmospheric CHartographY (SCIAMACHY). The comparisons between GNSS and satellite data are carried out for three reference Arctic observation sites (Sodankylä, Ny-Ålesund and Thule) where long homogeneous GNSS time series of more than a decade (20012014) are available. We select hourly GNSS data that are coincident with overpasses of the different satellites over the three sites and then average them into monthly means that are compared with monthly mean satellite products for different seasons. The agreement between GNSS and satellite time series is generally within $5 \%$ at all sites for most conditions. The weakest correlations are found during summer. Among all the satellite data, AIRS shows the best agreement with GNSS time series, though AIRS TCWV is often slightly too high in drier atmospheres (i.e. high-latitude stations during autumn and winter). SCIAMACHY TCWV data are generally drier than GNSS measurements at all the stations during the summer. This study suggests that these biases are associated with cloud cover, especially at Ny-Ålesund and
\end{abstract}

Thule. The dry biases of MODIS and SCIAMACHY observations are most pronounced at Sodankylä during the snow season (from October to March). Regarding SCIAMACHY, this bias is possibly linked to the fact that the SCIAMACHY TCWV retrieval does not take accurately into account the variations in surface albedo, notably in the presence of snow with a nearby canopy as in Sodankylä. The MODIS bias at Sodankylä is found to be correlated with cloud cover fraction and is also expected to be affected by other atmospheric or surface albedo changes linked for instance to the presence of forests or anthropogenic emissions. Overall, the results point out that a better estimation of seasonally dependent surface albedo and a better consideration of vertically resolved cloud cover are recommended if biases in satellite measurements are to be reduced in the polar regions.

\section{Introduction}

Water vapour has an important role in the Earth radiative balance (e.g. Kiehl and Trenberth, 1997; Trenberth and Stepaniak, 2003; Ruckstuhl et al., 2007; Trenberth et al., 2007), hydrologic cycle (e.g. Chahine, 1992; Serreze et al., 2006; Jones et al., 2007; Hanesiak et al., 2010) and climate change (e.g. Schneider et al., 1999, 2010; Held and Soden, 2000; Ramanathan and Inamdar, 2006; Rangwala et al., 2009). The rate of the Arctic climate change is two times larger than the global one due to greenhouse gas increase. The water vapour 
feedback loop is highlighted, as part of other feedback, as being responsible for the Arctic amplification (e.g. Winton, 2006; Francis and Hunter, 2007; Miller et al., 2007; Screen and Simmonds, 2010; Chen et al., 2011; Ghatak and Miller, 2013).

Water vapour measurements (total column and vertical profile information) using radiosondes have been available since the early 1940s and satellites since the 1980s primarily for meteorological purposes, while Global Positioning System (GPS) and more generally Global Navigation Satellite System (GNSS) measurements have been diverted from positioning to remote sensing of atmospheric water vapour since the 1990s (Bevis et al., 1992).

The total column of water vapour (TCWV), also called integrated water vapour (IWV), is defined as the density of water vapour in an atmospheric column over a unit area $\left(\mathrm{kg} \mathrm{m}^{-2}\right)$. It is also sometimes referred as precipitable water, which represents the height of liquid water (in $\mathrm{mm}$ ) resulting from the condensation of all the water vapour of a vertical column over a unit area.

TCWV is characterised by large spatial and temporal variability. It affects the water cycle intensity and the atmospheric dynamics (Sherwood et al., 2010; Trenberth et al., 2005). Since 2010, the Global Climate Observing System (GCOS) declared the TCWV to be an essential climate variable and highlighted the importance of high-resolution long time series that could enable the detection of both local and global TCWV trends.

The available satellite remote sensing techniques to observe TCWV in microwave (MW), infrared (IR), nearinfrared (NIR) and visible (VIS) spectral domains are promising, with a global coverage that enables climate studies, but with limited retrieval capability (e.g. only daytime, only clear skies, or over oceans only). Satellite observations are validated by ground-based techniques, traditionally radiosondes. However, radiosonde data sometimes suffer from systematic observational errors, as well as spatial and temporal inhomogeneity and instability (Gaffen, 1994; Wang, 2003), that could induce potentially regional biases if radiosondes alone are used to validate satellite data (Wang and Zhang, 2008, 2009; Bock and Nuret, 2009).

GNSS measurements complete the global radiosonde observations as another reliable reference to validate satellite water vapour retrievals and atmospherical models (e.g. Bock et al., 2007, and references therein). GNSS TCWV measurements are independent of the weather, performed with high temporal resolutions (a few minutes) and have continuously improved spatial resolution (from global down to a few kilometres for local networks). While GNSS is based on a delay measurement, it can be applied similarly to different sensors and is an ideal tool for long-term measurements, despite the presence of a possible bias in certain specific configurations (Ning et al., 2016).

Many studies comparing global satellite TCWV products with radiosonde, GPS and other reference data have pointed a dependence of bias and root mean square error (RMSE) on various observational factors like TCWV content (larger biases and RMSE are generally observed in regions with higher TCWV), reduced extreme values (e.g. wet bias at low TCWV values and dry bias at large values), solar zenith angle dependence (increased radiative transfer model error with larger zenith angles), day-night difference (increased background noise at daytime for VIS and NIR techniques), seasonal dependence (related to the two previous factors), latitudegeographical dependence (also partly connected with the former) and cloudiness dependence (usually increased biases and scatter with increasing cloudiness). Many of these aspects are discussed by (Vaquero-Martínez et al., 2017) for VIS, NIR and IR techniques over the Iberian Peninsula. Few studies investigated the polar and snow-covered regions. For example, Thomas et al. (2011) compared GPS to Moderate Resolution Imaging Spectroradiometer (MODIS) and Atmospheric Infrared Sounder (AIRS) over 13 Antarctic stations for 2004, and they found that GPS TCWV data are drier than MODIS, while wetter than AIRS. Palm et al. (2010) compared GPS with SCIAMACHY and GOME-2A data over Ny-Ålesund/Arctic and found GPS to underestimate both satellite sensors.

The current study provides intercomparisons of various measurements and methods allowing to quantify uncertainties, accuracies and limitations of several global satellite sensors/techniques available.

As common reference, we use a recently reprocessed version of GPS TCWV data with hourly temporal sampling covering the period from 1996 to 2014. It enables the largest number of coincident overpasses of three independent selected satellites AIRS IR (from 2003 to 2014), MODIS NIR (from 2001 to 2014) and SCIAMACHY VIS (from 2003 to 2011) for intercomparisons. Three Arctic groundbased GNSS observation sites were chosen: Ny-Ålesund $\left(78^{\circ} \mathrm{N}, 12^{\circ} \mathrm{E}\right)$, Thule $\left(76^{\circ} \mathrm{N}, 69^{\circ} \mathrm{W}\right)$ and Sodankylä $\left(67^{\circ} \mathrm{N}\right.$, $\left.26^{\circ} \mathrm{E}\right)$. Satellite gridded data were matched with these stations within a maximum spatial distance of $50 \mathrm{~km}$.

Generally, satellites measurements are more accurate during clear sky conditions. In this work we use only cloudcleared products in order to assess their uncertainties in optimal conditions in the Arctic region. However, cloud clearing is a challenging task. For this reason, we investigate the possible relation between satellite TCWV biases and the cloud cover at various timescales (seasonal and interannual, using time series with monthly, seasonal and annual sampling). In order to strengthen the conclusions, two different cloud fraction $(\mathrm{CF})$ products are used (from MODIS and AIRS measurements). Though cloudiness dependence is not the only error source in satellite TCWV retrievals, it is one of the least well known, especially for the Arctic region. The impact of clouds on TCWV retrievals is to shield partly or totally, depending on the cloud opacity, the underlying atmosphere, so that the observed radiance is only a measure of the water vapour content above the cloud. The mixing of cloudy pixels 
with clear pixels tends to lower the TCWV estimate and lead to a dry bias. In contrast, depending on wavelengths, multiple scattering inside the clouds may increase the observed radiance and lead to overestimation of the water vapour content above the cloud. These effects are usually corrected in the retrieval algorithms using different methods depending on the instrument. However, in the end, both under- and overestimation of the retrieved TCWV can be observed.

Section 2 describes the datasets used and discussed the error sources specific to each technique. Section 3 presents results of TCWV comparisons (satellite retrievals compared to GNSS). Section 4 investigates the link between observed biases in the satellite data and cloudiness. Section 5 presents conclusions.

\section{Description of the datasets}

\subsection{GNSS}

Originally designed for real-time navigation and positioning, GNSS was rapidly seen as a cheap and accurate technique for measuring TCWV from the ground (Bevis et al., 1992). The principle consists in estimating the propagation delay induced by the atmosphere of the microwave signals emitted by the GNSS satellites and received by ground-based receivers. The zenith tropospheric delay (ZTD) is usually parsed into its wet and hydrostatic components (ZWD and ZHD, respectively, for zenith wet delay and zenith hydrostatic delay). Accurate estimations of surface pressure and a weighted mean temperature are required to convert GNSS ZTD into TCWV using the following formulas (Bevis et al., 1992):

$\mathrm{ZWD}=\mathrm{ZTD}-\mathrm{ZHD}$,

where ZTD is the GNSS ZTD estimate. ZHD is computed from the surface pressure (Davis et al., 1985):

$\mathrm{ZHD}=0.002277 P_{\mathrm{sfc}} / f(\lambda, H)$,

where $P_{\mathrm{sfc}}$ is the surface pressure, $\lambda$ and $H$ are the latitude and altitude of the station, and $f(\lambda, H)$ accounts for the geographical variation of the mean acceleration due to gravity (Davis et al., 1985).

TCWV is converted from the ZWD as

$$
\mathrm{TCWV}=\mathrm{ZWD} \cdot K\left(T_{\mathrm{m}}\right),
$$

where $K\left(T_{\mathrm{m}}\right)$ is a delay to mass conversion factor and $T_{\mathrm{m}}$ is the humidity-weighted mean temperature (Bevis et al., 1992).

In this study, we used GNSS ZTD data from the Geodetic Observatory Pecny (Czech Republic) named "repro2 solution" and referred to as GO4 (Dousa et al., 2017). This ZTD dataset was produced with a homogeneous and optimised processing of GPS observations. Outliers in the ZTD time series were detected and removed using the range check

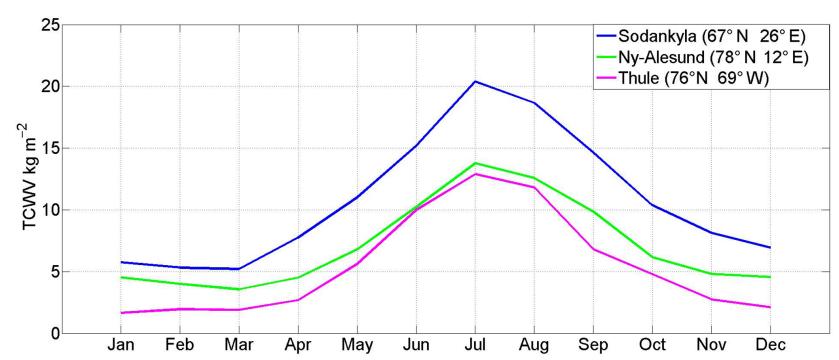

Figure 1. Annual cycle of TCWV from GNSS for the period 2004 to 2014 (in $\mathrm{kg} \mathrm{m}^{-2}$ ).

and outlier check method described in Bock et al. (2014). ZHD and $T_{\mathrm{m}}$ were computed from the ERA-Interim reanalysis pressure level data (37 vertical levels between 1000 and $1 \mathrm{hPa}, 0.75^{\circ} \times 0.75^{\circ}$ horizontal resolution, 6-hourly time resolution) (Dee et al., 2011). The data were first interpolated vertically to the height of the GNSS station and then interpolated horizontally (bilinear interpolation using the four grid points surrounding the station) to the location of the station. The 6-hourly $P_{\mathrm{sfc}}$ and $T_{\mathrm{m}}$ data were then interpolated (with cubic splines) to the times of the GNSS ZTD data resulting in the final 1-hourly GNSS TCWV dataset.

In order to overcome the satellite/GNSS timing error due to limited hours of MODIS, AIRS and SCIAMACHY measurements during a month over a fixed point at the surface, the satellites passing hours over the three Arctic GNSS stations were defined through the IXION software (http: //climserv.ipsl.polytechnique.fr/ixion/index.php, last access: 15 May 2018). For each satellite, only GNSS TCWV corresponding to the overpasses less than $1 \mathrm{~h}$ (Table 1) was used to calculate the corresponding monthly time series.

Seasonal variations of the TCWV over all three sites for a common period of 11 years (2004-2014) exhibit a pronounced seasonal cycle (Fig. 1) with mean values ranging from a maximum in July of 20,14 and $13 \mathrm{~kg} \mathrm{~m}^{-2}$ to a minimum in winter of $6,4.5$ and $2 \mathrm{~kg} \mathrm{~m}^{-2}$ over Sodankylä, $\mathrm{Ny}-$ Ålesund and Thule, respectively.

Extreme hourly values could reach $40 \mathrm{~kg} \mathrm{~m}^{-2}$ (not shown) over Sodankylä. This highest amplitude appears in summer under continental climate conditions. Ny-Ålesund and Thule have likely similar seasonal features. However, Thule has drier winter/autumn periods due to the Greenland ice sheet climate effect. Figure 2 shows that the year-to-year variations of TCWV at the three stations are smaller than the seasonal cycle (Fig. 1). This can be easily seen for summer values (peak values).

\subsection{MODIS}

MODIS is installed on both platforms (Terra and Aqua) of the Earth Observing System (EOS). Both satellites are launched on polar orbits since 1999 (Terra) and 2002 (Aqua). They overpass the equator at 10:30 and 13:30, respectively. 
Table 1. Over passing hours of each sensor in universal time (UT) at three GNSS sites.

\begin{tabular}{llll}
\hline Station/instrument & MODIS (UT) & SCIAMACHY (UT) & AIRS (UT) \\
\hline Sodankylä $\left(67^{\circ} \mathrm{N}, 26^{\circ} \mathrm{E}\right)$ & $08: 00-12: 00$ and 17:00-21:00 & $08: 00-11: 00$ and 17:00-20:00 & $09: 00-12: 00$ and 23:00-03:00 \\
Thule $\left(76^{\circ} \mathrm{N}, 69^{\circ} \mathrm{W}\right)$ & $15: 00-04: 00$ & $16: 00-20: 00$ and 22:00-02:00 & $06: 00-19: 00$ \\
Ny-Ålesund $\left(78^{\circ} \mathrm{N}, 12^{\circ} \mathrm{E}\right)$ & $09: 00-22: 00$ & $10: 00-20: 00$ & $23: 00-13: 00$ \\
\hline
\end{tabular}

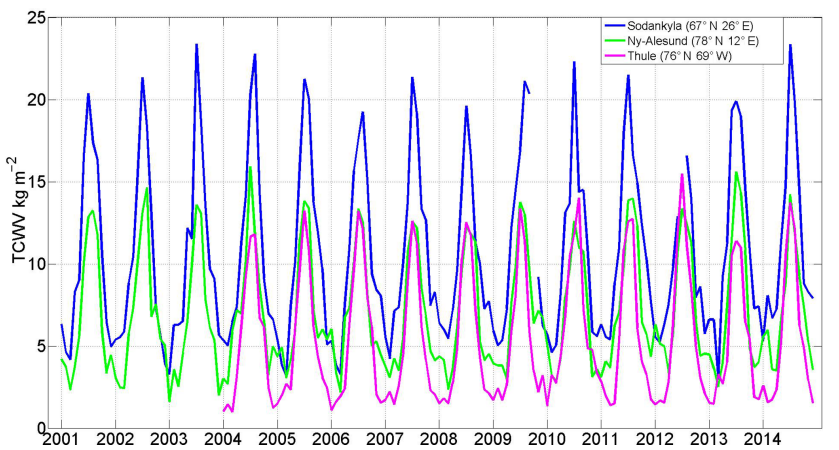

Figure 2. Monthly time series of TCWV from GNSS over the full period of observation at each site (in $\mathrm{kg} \mathrm{m}^{-2}$ ).

The global coverage is provided within 1-2 days, through a nadir-looking geometry at a solar zenith angle of $45^{\circ}$. The spatial resolution varies between $250 \mathrm{~m}$ and $1 \mathrm{~km}$ per pixel depending on the spectral band.

MODIS observes the NIR solar radiation reflected by sufficiently bright surfaces and clouds and IR thermal emission in 36 channels covering the spectral region $0.4-14.4 \mu \mathrm{m}$. It allows the measurement of many other trace gases in addition to clouds and aerosols. In this study we use only the NIR data as they are known to be more accurate.

Five NIR channels are used for retrieving daytime water vapour. They are centred on $0.865,0.905,0.936,0.94$ and $1.240 \mu \mathrm{m}$, in which all the surface types are sufficiently bright (albedo $>0.1)$. The extreme channels $(0.865$ and $1.240 \mu \mathrm{m})$ have no water vapour absorption features. They are used to estimate the surface reflectance. The three other channels $(0.905,0.936$ and $0.94 \mu \mathrm{m})$ absorb water vapour with different sensitivity. The $0.936 \mu \mathrm{m}$ channel has the strongest absorption sensitivity. TCWV is derived by a differential absorption technique involving channels with absorption and channels without. The accuracy of this product is claimed to be $5-10 \%$ (Gao and Kaufman, 2003). Main uncertainties concern the spectral reflectance of surface targets and the uncertainty in the amount of haze for dark surfaces under typical atmospheric conditions (Gao and Kaufman, 2003).

The TCWV data used in this study are from version 6 of the MODIS instrument on board Terra platform, referenced as "Water vapour near infrared - clear column (bright land and ocean sunglint only): mean of daily mean" (Gao and Kaufman, 2003; Hubanks et al., 2008). The Aqua platform was not used because of many gaps in the measurement. We retrieved global monthly mean files, gridded at $1^{\circ}$ by $1^{\circ}$, from the MOD08_M3.006 data stream ${ }^{1}$ freely available at ftp: //ladsweb.nascom.nasa.gov/allData/6/MOD08_M3 (last access: 15 May 2018).

We extracted TCWV from 2001 to 2014 for Sodankylä and Ny-Ålesund and from 2004 to 2014 for Thule for the comparison with GPS. The pixel selection method is the following. MODIS data coordinates refer to the centre of each gridded pixel, so a single pixel is considered per station (to avoid interpolation and select the nearest pixel to GNSS/IGS stations) and defined as follows:

(lat, long $)_{(\text {pixel })}=(\text { lat, long })_{(\text {station })}+\left(0.5^{\circ}, 0.5^{\circ}\right)$,

where (lat, long) $)_{\text {station }}$ is defined in Table 1 for each of the three stations.

For example, the Sodankylä MODIS pixel was selected as follows:

$$
\begin{aligned}
(\text { lat, long })_{(\text {Soda })} & =\left(67^{\circ}, 26^{\circ}\right)_{(\text {Table } 1)}+\left(0.5^{\circ}, 0.5^{\circ}\right) \\
& =\left(67.5^{\circ}, 26.5^{\circ}\right) .
\end{aligned}
$$

MODIS CF (Hubanks et al., 2008; Platnick et al., 2003) taken from the same atmospheric product (MOD08_M3.006) is used also to test the sensitivity of the satellite measurements to the presence of clouds. This product is thought to be efficiently capable to detect low-level clouds in dry atmospheres (Ackerman et al., 2008). MODIS CF is defined as the ratio of the count of the lowest two clear sky confidence levels (cloudy and probably cloudy) to the total count of scenes per $1^{\circ} \times 1^{\circ}$.

\subsection{SCIAMACHY}

Launched on board the satellite ENVISAT-1 in March 2002, the Scanning Imaging Absorption spectrometer for Atmospheric CHartographY (SCIAMACHY) was designed to observe the earthshine radiance and the solar irradiance within limb and nadir alternating viewing geometry. SCIAMACHY nadir and limb observations cover the spectra from ultraviolet (UV) to NIR (214-2380 nm) at moderate spectral resolution $(0.2-1.5 \mathrm{~nm})$. The observed spectra enable the measurement of many other trace gases, as well as clouds and aerosols.

SCIAMACHY can measure water vapour at various wavelengths from the VIS to the SWIR (shortwave infrared). This

\footnotetext{
${ }^{1}$ Dataset DOI: https://doi.org/10.5067/MODIS/MOD08_M3.006 (Platnick et al., 2015)
} 
paper uses TCWV retrieved by the air-mass-corrected differential optical absorption spectroscopy method, shortly AMCDOAS (Noël et al., 2004), where water vapour is measured in nadir mode in the visible part of the spectrum between 688 and $700 \mathrm{~nm}$. This method makes use of the similar slant optical depth of both $\mathrm{O}_{2}$ and water vapour to determine an air mass correction factor (AMF), which compensates for insufficient knowledge of the atmospheric and topographic background, like surface elevation and clouds. AMF includes a correction for the part of the atmosphere below the cloud, but this relies on some assumptions (e.g. about profile shapes) which might lead to under- or overcorrection of TCWV values.

Though SCIAMACHY TCWV measurements are independent of the initial humidity profile, they are affected by other factors. A dominant error source in SCIAMACHY TCWV retrieval is caused by uncertainties of the atmospheric radiative transfer, mainly due to effects of varying cloud cover and surface albedo for different surfaces (Wagner et al., 2011) This error source is estimated to be about $15 \%$ for clear sky observations, and up to $100 \%$ in large clouds amounts (Van Malderen et al., 2014). The sensitivity to the surface albedo may cause deviations of up to about $15 \%$, or $6 \mathrm{~kg} \mathrm{~m}^{-2}$ in regions of high surface albedo (Noël, 2007a; Noël et al., 2004). A scatter of about $5 \mathrm{~kg} \mathrm{~m}^{-2}$, caused by atmospheric variability, is usually observed during the intercomparison with other TCWV datasets (Noël, 2007b).

The three stations used in this study were part of the ground-based stations contributing to the SCIAMACHY validation effort (Piters et al., 2006) during which water vapour profiles alone were validated over Thule and Sodankylä, while TCWV was additionally validated over Ny-Ålesund.

TCWV data used in this paper are from Noël et al. (2004), where all observations with $\mathrm{AMF}<0.8$ were removed, as well as those performed at solar zenith angles larger than $88^{\circ}$. We apply an extra screening that excludes data with SCIAMACHY indicated error $>20 \%$ (fitting error) and swath data of spatial distance more than $50 \mathrm{~km}$ (actually $54 \mathrm{~km}$ ) to the station coordinates defined by Table 1 .

This collocation is made by choosing data that meet the conditions

$\left|\operatorname{lat}_{(\text {data) }}-\operatorname{lat}_{(\text {station })}\right| \leq 0.5^{\circ}$ and
$\left|\operatorname{long}_{\text {(data) }}-\operatorname{long}_{(\text {station })}\right| \leq 0.2^{\circ}$.

This surface is defined according to SCIAMACHY swath data footprints size which is about $30 \mathrm{~km} \times 60 \mathrm{~km}$.

Then, SCIAMACHY TCWV monthly means are calculated from all the matched data to the given station. Note that SCIAMACHY data solar dependency results in missing data for winter months. Our study takes place from 2003 to 2011 over Sodankylä and Ny-Ålesund and from 2004 to 2011 for Thule.

\subsection{AIRS}

The AIRS is carried on Aqua (EOS) since May 2002. This platform has an equatorial over passing at 13:30 with a sun-synchronous orbit. AIRS was dedicated to water cycle, energy and traces gases observations. It provides twice daily global coverage with higher vertical resolutions than all previous sensors and comparable accuracy to radiosondes (Tobin et al., 2006). AIRS is a hyperspectral scanning infrared sounder. It measures upwelling thermal radiation emitted from the atmosphere and the surface. However, almost $30 \%$ of the AIRS radiances could be trapped below clouds (Susskind et al., 2006). These possible profiles could be better retrieved using simultaneous observations from the Advanced Microwave Sounding Unit (AMSU) (Lambrigtsen, 1999) in a process called "cloud clearing" (Susskind et al., 2003). The observation geometry of these combined measurements or the AIRS field of regard (FOR) is called "AIRS golf ball".

Humidity profiles (level 2 products) are retrieved from cloud-cleared radiances (level 1). A set of different water vapour sensitive channels are used in addition to temperature sensitive channels. Water vapour mixing ratios at certain pressure levels are retrieved using the radiative transfer algorithm AIRS-RTA described by Strow et al. (2003). TCWV is obtained by integrating the vertical profile of water vapour mixing ratio.

The RMSE of the AIRS water vapour profiles is estimated to $10-15 \%$ over $2 \mathrm{~km}$ layers in the troposphere (Divakarla et al., 2006; Fetzer et al., 2003). Several studies have confirmed that both the AIRS radiances and the AIRS clear sky forward model have an absolute accuracy of around $0.2 \mathrm{~K}$ for the spectral channels used in temperature and water vapour retrievals (Fetzer et al., 2003; Strow et al., 2006). AIRS TCWV retrievals are mainly limited by the accurate initialisation of the humidity profile (Fetzer et al., 2006).

Previous versions of AIRS TCWV were validated against radiosondes over oceanic areas (Fetzer et al., 2006) and against reanalysis (ECMWF) (Susskind et al., 2006). Gettelman et al. (2006) showed that AIRS retrievals in polar regions are unbiased relative to in situ radiosondes. Most results indicate a small mean bias that does not exceed $10 \%$ with no significant dependency upon cloud amount.

AIRS TCWV data ${ }^{2}$ used in this study are from the version 6 , monthly weighted means, level 3 product, referenced as AIRX3STM.006. It presents a standard physical retrieval that includes both AIRS and AMSU radiances (Susskind et al., 2014). This dataset has dense orbital coverage at high latitude. Similarly to MODIS data, the $1^{\circ}$ by $1^{\circ}$ gridded AIRS pixels were screened. The AIRS considered TCWV pixel per station is the same as for MODIS and defined by Eq. (3). The comparison to GNSS is done from 2003 to 2014 for So-

\footnotetext{
${ }^{2}$ https://disc.gsfc.nasa.gov/datasets/AIRX3STM_V006/ summary?keywords=airs20version206 (last access: 15 May 2018)
} 
dankylä and Ny-Ålesund and from 2004 to 2014 for Thule according to AIRS and GNSS data availability.

During this study, we additionally use the AIRS effective CF (Kahn et al., 2014) monthly $1^{\circ}$ by $1^{\circ}$ dataset from the same atmospheric product (AIRX3STM.006) in order to investigate possible effects of cloud interference on the satellite's observed biases. The AIRS effective CF product is the multiplication of spatial cloud fraction and cloud emissivity. AIRS cloud fraction is defined as the ratio of the number of AIRS cloudy measurements $(\mathrm{CF}>0.01)$ to the total number of AIRS measurements per $1^{\circ}$ by $1^{\circ}$.

\section{Mean seasonal comparisons and discussion}

\subsection{GNSS vs. MODIS}

MODIS time series of monthly means TCWV are compared to monthly means of coincident overpassing (mentioned in Table 1) GNSS data over Sodankylä and Ny-Ålesund for the period 2001-2014 and over Thule for 2004-2014. This difference in the data range is linked to the GNSS data availability, as GNSS dataset has some missing values at Thule during 2001-2003. The results show an excellent overall agreement with a high coefficient of correlation $R>96 \%$ for the monthly time series (Table 2). High correlation of the monthly time series is indeed expected since the seasonal cycle is very marked at all three sites (Fig. 2). The mean biases are $+0.4,+0.6$ and $+1.7 \mathrm{~kg} \mathrm{~m}^{-2}$ at Ny-Ålesund, Thule and Sodankylä, respectively (Table 2). The overall positive biases indicate that MODIS generally underestimates TCWV compared to GPS. This was previously reported over other cold regions of the world, using other versions of GNSS and MODIS data, for example, over the Tibetan plateau for both stations Gaize and Naque (Liu et al., 2006). Here we can also note a latitudinal decrease both in the absolute bias (in $\mathrm{kg} \mathrm{m}^{-2}$ ) and the relative bias, as well as in the RMSE, which means that the TCWV retrieval is actually more accurate at higher latitudes.

The mean biases and interannual variability of the individual months are analysed with box plots in Fig. 3. A seasonal variation can be seen at all three sites in the bias and in the dispersion (see the interquartile range in the box plots). The largest variations are observed at Sodankylä with large positive biases between September and February and slightly negative biases between July and August.

Dividing the year into four seasons, the statistics were also calculated and given in Table 2. At Ny-Ålesund and Thule the relative bias does not exceed $13 \%$ regardless of the season and the absolute biases are larger in (June-July-August) JJA and SON (September-October-November). A small wet bias is observed at Ny-Ålesund during spring which was also reported for Antarctica during the transition seasons (Thomas et al., 2011). The interannual variability is best represented for the DJF (December-January-February) and
SON seasons at both high-latitude sites ( $\mathrm{Ny}-\AA$ Alesund and Thule) with correlations in the range $56-83 \%$ (all significant) but quite poorly in JJA with correlation values of 10 and $15 \%$ (not significant). The larger biases and lower correlations in JJA are linked with cloud cover (see Sect. 4).

At Sodankylä, the results are more complex to interpret. Multiple factors are involved with the observed biases including clouds. During the snow season, which lasts from October to April at Sodankylä, the solar angle has a strong influence on the effective albedo, since Sodankylä is totally covered with canopy, unlike both other stations, and its forests intercept the majority of incoming solar radiation, as pointed out by Gryning et al. (2002). Additionally, Sodankylä snow samples contain higher impurity concentrations (black carbon) than measured elsewhere in Arctic Scandinavia or Greenland (Doherty et al., 2010), as well as a bigger snow grain size. These two factors contribute to a decrease in surface albedo (Meinander et al., 2013). The chemical exchange between polluted atmospheric layers due to winter biomass burning and snow surface opaque the lower part of the atmosphere at the instrument's wavelengths. Since the MODIS retrieval capacities are sensitive to surface albedo and atmospheric transmittance (Sect. 2.2), the seasonal variation in these parameters and could explain the variation in the MODIS TCWV bias, especially the dry bias during the snow season at Sodankylä. During summer at Sodankylä, MODIS TCWV estimates were found higher than GNSS TCWV measurements. This opposite bias can be explained by the fact that the snow coverage nearly disappeared, in addition to the tendency of increasing MODIS TCWV with increasing water vapour at sites below $3000 \mathrm{~m}$ (Lu et al., 2011). This bias is also found to be correlated with MODIS CF (Sect. 4).

\subsection{GNSS vs. SCIAMACHY}

Calculated monthly means of SCIAMACHY TCWV over Sodankylä and Ny-Ålesund for 2003-2011 and over Thule for 2004-2011 were compared to means of coincident GNSS measurements. This comparison does not include winter pairs over Thule and Ny-Ålesund because of missing SCIAMACHY measurements during polar winter. Similarly to MODIS, SCIAMACHY underestimates TCWVs at all three sites with mean absolute biases between 0.6 and $2.4 \mathrm{~kg} \mathrm{~m}^{-2}$ and relative biases between 6 and $22 \%$ (Table 2, monthly mean biases). The dry bias agrees well with previous findings at high-latitude sites by Van Malderen et al. (2014) using different versions/retrieval methods of both GNSS and SCIAMACHY data (namely their SCIAMACHY data were completed with TCWV data from other satellites to achieve higher time sampling and temporal coverage). A good overall correlation is observed between SCIAMACHY and GNSS monthly time series with $R>90 \%$ and RMSE between 24 and $27 \%$. The monthly mean biases (Fig. 4) show also a marked seasonal variation at all three sites. The absolute bi- 
Table 2. Bias, RMSE and linear correlation coefficient between MODIS NIR, SCIAMACHY VIS, AIRS IR clear column TCWV retrievals and GNSS TCWV estimates, at Ny-Ålesund $\left(78^{\circ} \mathrm{N}, 12^{\circ} \mathrm{E}\right)$, Thule $\left(76^{\circ} \mathrm{N}, 69^{\circ} \mathrm{W}\right)$ and Sodankylä $\left(67^{\circ} \mathrm{N}, 26^{\circ} \mathrm{E}\right)$. Correlations with significance level $>95 \%$ are in bold.

\begin{tabular}{|c|c|c|c|c|c|c|c|c|}
\hline & Stat & ion (Period) & Season & Number of pairs & $\operatorname{Bias}\left(\mathrm{kg} \mathrm{m}^{2}\right)$ & Bias (\%) & RMSE (\%) & $R(\%)$ \\
\hline \multirow{15}{*}{ 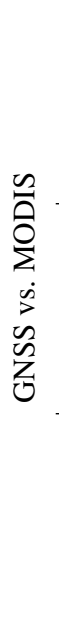 } & \multirow{5}{*}{ 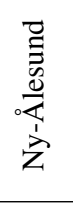 } & \multirow{5}{*}{ 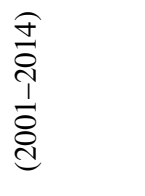 } & Monthly & 168 & 0.4 & 3 & 18 & 96 \\
\hline & & & DJF & 13 & 0.4 & 9 & 14 & 77 \\
\hline & & & MAM & 14 & 0.0 & -0.6 & 14 & 58 \\
\hline & & & JJA & 14 & 0.6 & 4 & 7 & 10 \\
\hline & & & SON & 14 & 0.8 & 12 & 13 & 56 \\
\hline & \multirow{5}{*}{$\begin{array}{l}\frac{0}{\Xi} \\
E\end{array}$} & \multirow{5}{*}{ 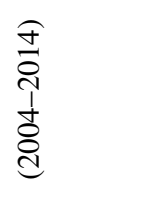 } & Monthly & 132 & 0.6 & 10 & 16 & 98 \\
\hline & & & DJF & 10 & 0.3 & 13 & 17 & 83 \\
\hline & & & MAM & 11 & 0.4 & 10 & 13 & 71 \\
\hline & & & JJA & 11 & 1.1 & 10 & 14 & 15 \\
\hline & & & SON & 11 & 0.6 & 13 & 14 & 83 \\
\hline & \multirow{5}{*}{ 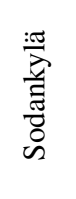 } & \multirow{5}{*}{ 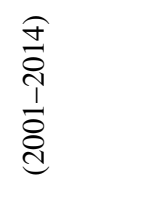 } & Monthly & 166 & 1.7 & 24 & 33 & 96 \\
\hline & & & DJF & 13 & 2.8 & 47 & 48 & 30 \\
\hline & & & MAM & 14 & 1.5 & 18 & 19 & 74 \\
\hline & & & JJA & 14 & -1.1 & -6 & 9 & 41 \\
\hline & & & SON & 14 & 3.5 & 32 & 32 & 76 \\
\hline \multirow{15}{*}{ 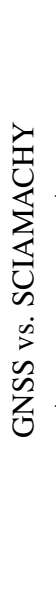 } & \multirow{5}{*}{ 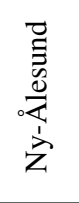 } & \multirow{5}{*}{ 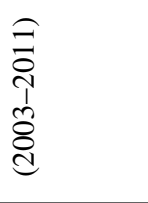 } & Monthly & 81 & 1.5 & 22 & 27 & 97 \\
\hline & & & DJF & - & - & - & - & - \\
\hline & & & MAM & 9 & 1.1 & 22 & 23 & 81 \\
\hline & & & JJA & 9 & 1.7 & 14 & 14 & 76 \\
\hline & & & SON & 9 & 1.9 & 24 & 25 & 76 \\
\hline & \multirow{5}{*}{ 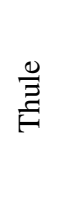 } & \multirow{5}{*}{ 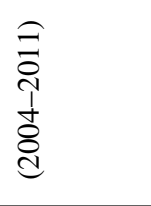 } & Monthly & 72 & 0.6 & 6 & 24 & 96 \\
\hline & & & DJF & - & - & - & - & - \\
\hline & & & MAM & 8 & -0.2 & -5 & 9 & 88 \\
\hline & & & JJA & 8 & 1.1 & 10 & 11 & 69 \\
\hline & & & SON & 8 & 1.4 & 25 & 26 & 90 \\
\hline & \multirow{5}{*}{ 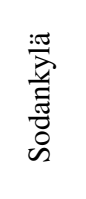 } & \multirow{5}{*}{ 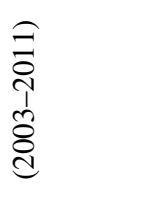 } & Monthly & 98 & 2.4 & 19 & 25 & 90 \\
\hline & & & DJF & 8 & 1.1 & 21 & 27 & 26 \\
\hline & & & MAM & 9 & 1.4 & 17 & 18 & 71 \\
\hline & & & JJA & 9 & 4.9 & 27 & 29 & 19 \\
\hline & & & SON & 9 & 1.8 & 16 & 18 & 48 \\
\hline \multirow{15}{*}{ 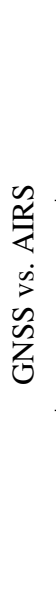 } & \multirow{5}{*}{ 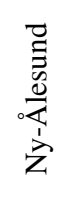 } & \multirow{5}{*}{ 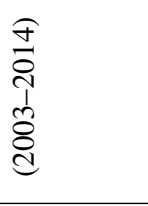 } & Monthly & 144 & -0.1 & -8 & 19 & 98 \\
\hline & & & DJF & 11 & -0.8 & -22 & 26 & 83 \\
\hline & & & MAM & 12 & -0 & -2 & 4 & 97 \\
\hline & & & JJA & 12 & 1 & 9 & 9 & 94 \\
\hline & & & SON & 12 & -0.6 & -8 & 9 & 96 \\
\hline & \multirow{5}{*}{$\frac{\mathscr{D}}{\Xi}$} & \multirow{5}{*}{$\begin{array}{l}\text { త্ } \\
\text { d } \\
\text { ḋ } \\
\stackrel{d}{d}\end{array}$} & Monthly & 132 & -0.3 & -18 & 31 & 99 \\
\hline & & & DJF & 11 & -0.8 & -41 & 44 & 97 \\
\hline & & & MAM & 11 & -0.3 & -9 & 14 & 85 \\
\hline & & & JJA & 11 & 0.5 & 4 & 5 & 82 \\
\hline & & & SON & 11 & -0.5 & -11 & 12 & 92 \\
\hline & \multirow{5}{*}{ 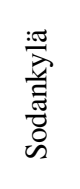 } & \multirow{5}{*}{ 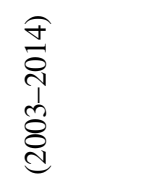 } & Monthly & 142 & 1 & 9 & 14 & 98 \\
\hline & & & DJF & 11 & 0.8 & 13 & 17 & 50 \\
\hline & & & MAM & 12 & 0.7 & 9 & 9 & 90 \\
\hline & & & JJA & 12 & 1.5 & 8 & 10 & 64 \\
\hline & & & SON & 12 & 1 & 8 & 11 & 58 \\
\hline
\end{tabular}




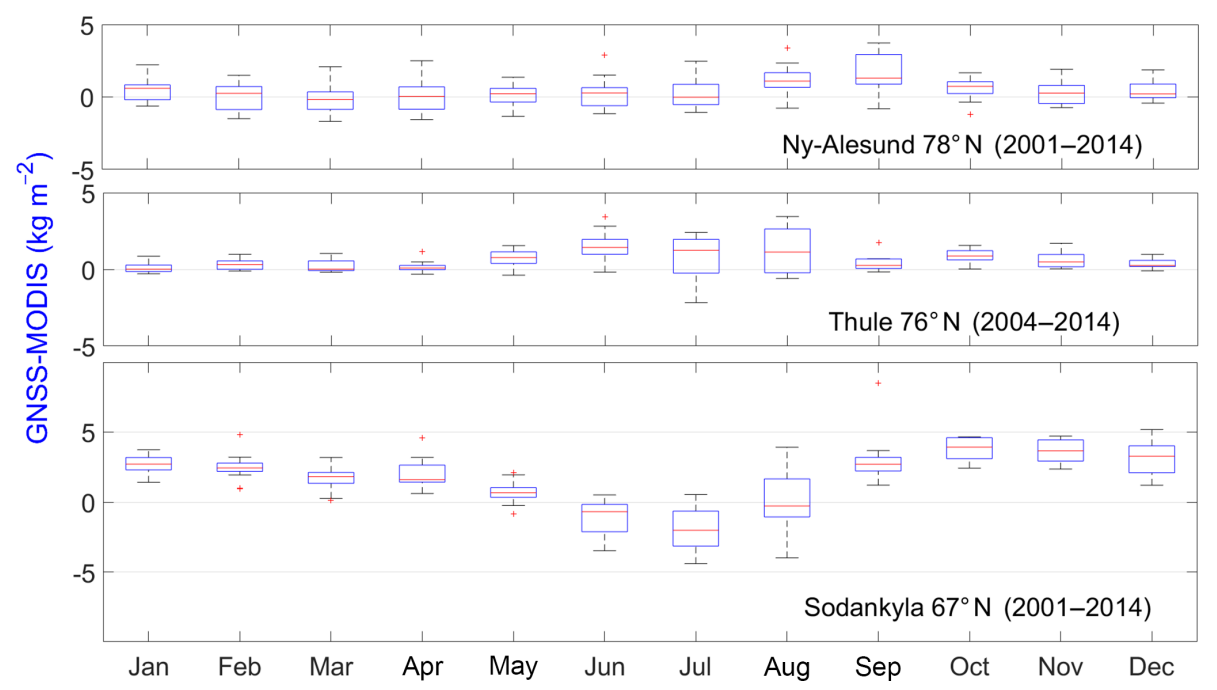

Figure 3. Box plot of the TCWV differences (GNSS - MODIS) for 2001-2014 at Sodankylä $\left(67^{\circ} \mathrm{N}, 26^{\circ} \mathrm{E}\right)$ and Ny- $\mathrm{Alesund}\left(78^{\circ} \mathrm{N}, 12^{\circ} \mathrm{E}\right)$ and at Thule $\left(76^{\circ} \mathrm{N}, 69^{\circ} \mathrm{W}\right)$ for $2004-2014 \mathrm{in} \mathrm{kg} \mathrm{m}^{-2}$. The central red mark indicates the median absolute TCWV difference of the month for the whole period; blue boxes indicate the 25 th and 75 th percentiles, respectively; black bars (whiskers) extend to \pm 1.5 times the interquartile range from the median; outliers are displayed using the "+" symbol.

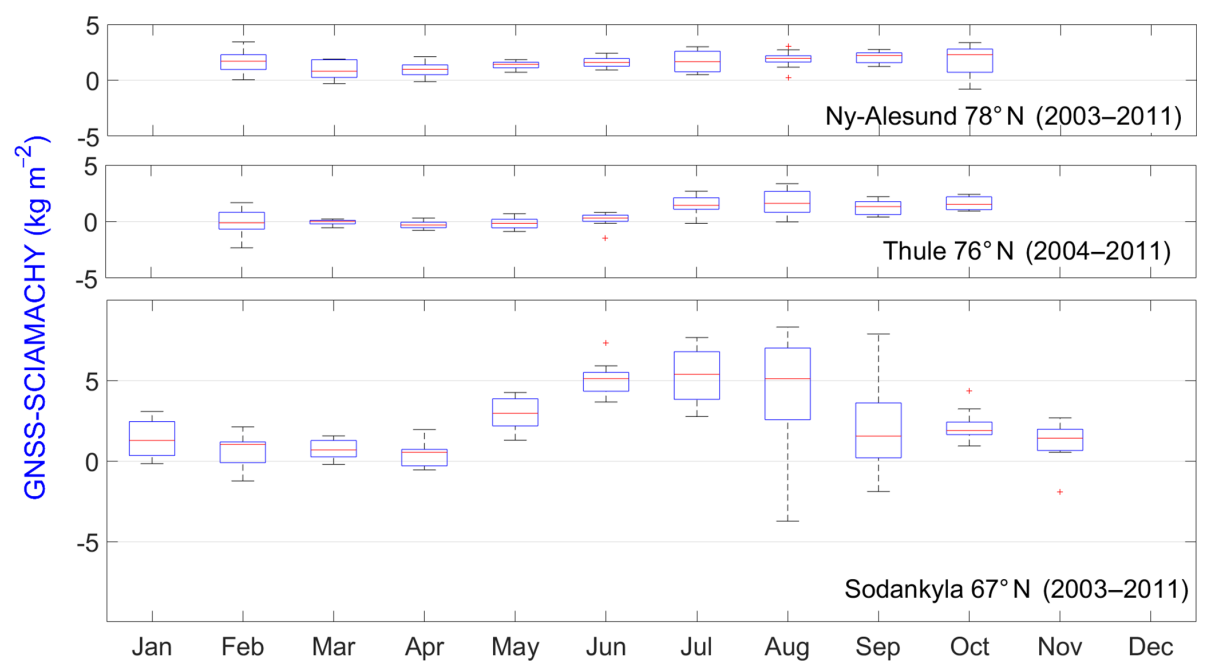

Figure 4. Box plot of the difference (GNSS - SCIAMACHY) at Sodankylä $\left(67^{\circ} \mathrm{N}, 26^{\circ} \mathrm{E}\right)$ and Ny-Ålesund $\left(78^{\circ} \mathrm{N}, 12^{\circ} \mathrm{E}\right)$ for $2003-2011$

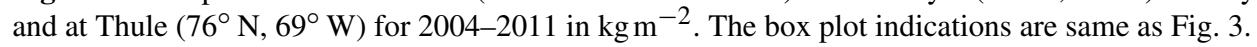

ases show a similar seasonality at all stations, having their minimum during spring and maximum during summer or autumn. At Ny-Ålesund and Thule, the dry biases are the largest during SON and JJA, similar to MODIS but with different magnitudes. At Sodankylä the bias is around $5 \mathrm{~kg} \mathrm{~m}^{-2}$ in JJA, i.e. much larger and of opposite sign compared to MODIS (Table 2). The seasonal RMSE values are generally larger as well compared to MODIS at Ny-Ålesund and Thule but smaller at Sodankylä, where they do not exceed $30 \%$. Interannual variability is generally well represented by SCIAMACHY at Ny-Ålesund and Thule $(R>76 \%$ significant in all seasons except at Thule in JJA). At Sodankylä the cor- relations are much smaller, similar to what we found with MODIS.

Consideration of surface albedo of complex surfaces could be also a challenge for the SCIAMACHY TCWV retrieval. The presence of snow with a nearby canopy (e.g. in Sodankylä) might result in a surface albedo significantly different from the prescribed surface albedo used in the AMCDOAS method (e.g. 0.05 compared to 0.5), which would explain the winter biases (Noël, 2007b). Nevertheless, the DJF and SON absolute TCWV biases found here with SCIAMACHY are smaller than those found with MODIS. They are also smaller than those expected for SCIAMACHY in 


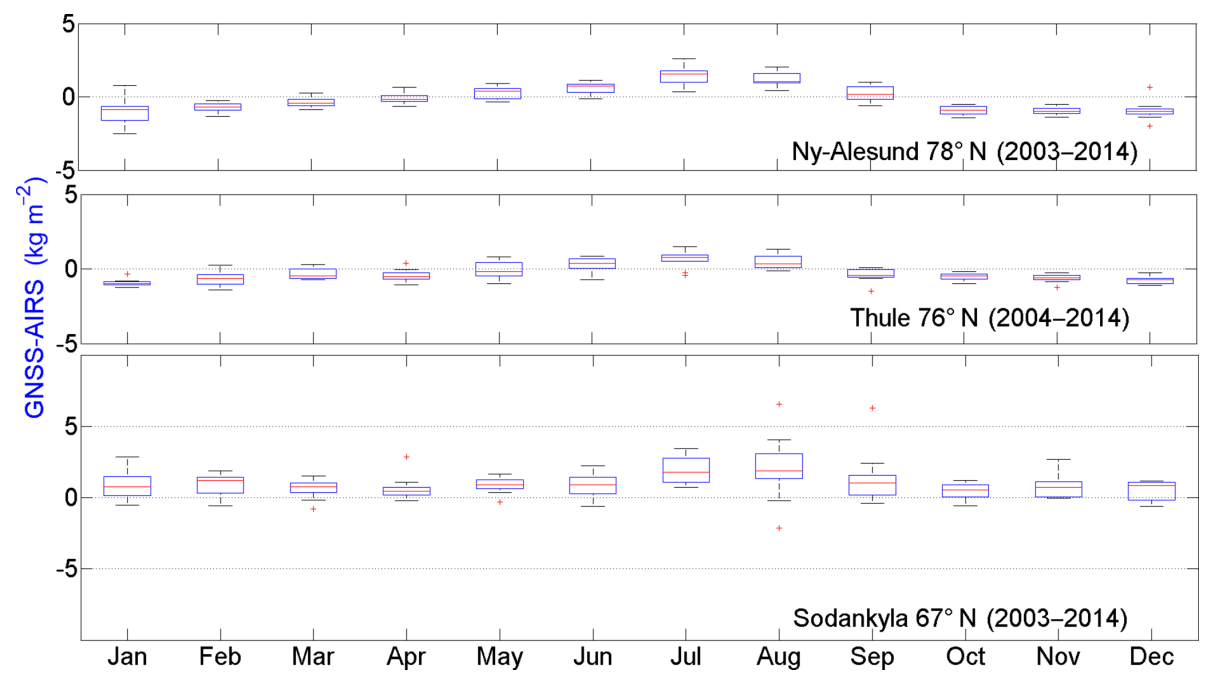

Figure 5. Box plot of the difference (GNSS - AIRS) for 2003-2014 at Sodankylä $\left(67^{\circ} \mathrm{N}, 26^{\circ} \mathrm{E}\right)$ and $\mathrm{Ny}-\AA \AA^{\circ}$ lesund $\left(78^{\circ} \mathrm{N}, 12^{\circ} \mathrm{E}\right)$ and for 2004-2014 at Thule $\left(76^{\circ} \mathrm{N}, 69^{\circ} \mathrm{W}\right)$ in $\mathrm{kg} \mathrm{m}^{-2}$. The box plot indications are same as Fig. 3 .

such conditions (Noël, 2007b). However, the JJA bias at Sodankylä is the most challenging and yet unexplained issue.

\subsection{GNSS vs. AIRS}

The AIRS TCWV monthly product shows excellent agreement with coincident GNSS measurements at all stations. The overall correlation with GNSS is larger than $98 \%$, and the mean bias is smaller than $1 \mathrm{~kg} \mathrm{~m}^{-2}$ in absolute value (Table 2). These biases are in the same range as reported in previous studies over cold regions, e.g. Thomas et al. (2011) over Antarctica. However, our study uses a more recent and improved version of both AIRS and GNSS datasets. Again, the monthly mean biases show a distinct seasonal variation at all three sites (Fig. 5). AIRS is found to be biased wet compared to GNSS during the colder and drier periods and biased dry during the moister months over Ny-Ålesund and Thule (Fig. 5). This observed wet-dry seasonal variation of the bias is consistent with the previous validation efforts of Rama Varma Raja et al. (2008) and of Van Malderen et al. (2014). The bias at Sodankylä follows similar seasonal variation but with an overall offset (the bias is always positive). The interannual variability is globally much better reproduced by AIRS than the two previous sensors, as attested by the correlation coefficients $>64 \%$ (all significant except one). The correlations are higher over Ny-Ålesund and Thule than Sodankylä. Compared to MODIS and SCIAMACHY, the results are noticeably better at Sodankylä (seasonal bias and RMSE $<13$ and $17 \%$, respectively). So there must be a significantly different sensitivity in the measurements to the atmospheric properties over Sodankylä. In the next section we investigate more specifically the impact of cloud cover on the TCWV retrievals from all three sensors.

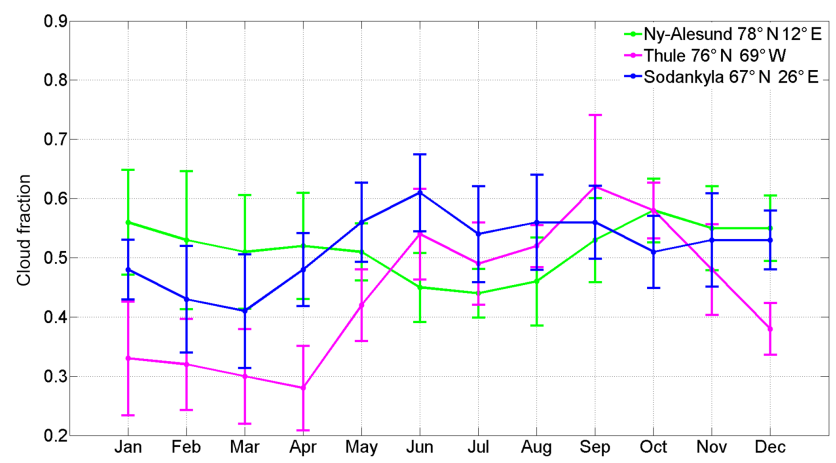

Figure 6. Annual cycle of AIRS cloud fraction for 2004-2014; the error bars show the standard deviation $(1 \sigma)$ of the annual means per month.

\section{Cloud impact on TCWV observations}

MODIS and SCIAMACHY TCWV measurements are known to be sensitive to the presence of clouds, whereas the AIRS TCWV product is less impacted by clouds as it includes microwave water vapour measurements and a robust cloud clearing technique also based on microwave measurements (Susskind et al., 2003). This section uses the AIRS and MODIS CF products to examine the correlations between the TCWV biases found in Sect. 3 and cloud cover. The use of both products helps to minimise the influence of different overpasses between clouds fraction and satellites measurements. In this study, AIRS and MODIS cloud fractions show similar annual cycles only at Thule. This is not surprising, as previous comparisons between both cloud fractions showed the largest disagreement over the high latitudes (e.g. Wu et al., 2009). The observed inconsistencies in both cloud fractions are expected to be dominated by retrieval al- 
Table 3. Correlation coefficients (\%) between TCWV biases and coincident cloud cover (AIRS) at Sodankylä (SODA) $\left(67^{\circ} \mathrm{N}, 26^{\circ} \mathrm{E}\right), \mathrm{Thule}^{\circ}$ (THUL) $\left(76^{\circ} \mathrm{N}, 69^{\circ} \mathrm{W}\right)$, and Ny-Ålesund (NYAL) $\left(78^{\circ} \mathrm{N}, 12^{\circ} \mathrm{E}\right)$ for all months, annual cycle and interannual variability (by season and by month). Correlations with significance level $>95 \%$ are in bold.

\begin{tabular}{|c|c|c|c|c|c|c|c|c|c|}
\hline & \multicolumn{3}{|c|}{ MODIS } & \multicolumn{3}{|c|}{ SCIAMACHY } & \multicolumn{3}{|c|}{ AIRS } \\
\hline & SODA & THUL & NYAL & SODA & THUL & NYAL & SODA & THUL & NYAL \\
\hline Monthly & -3 & 39 & 44 & 29 & 60 & 26 & 12 & 31 & -42 \\
\hline An-cycle & -38 & 68 & 6 & 75 & 75 & -19 & 36 & 42 & -94 \\
\hline DJF & 43 & 69 & 53 & -49 & - & - & -18 & 44 & -63 \\
\hline MAM & 46 & 15 & 58 & -37 & 18 & 5 & 4 & 9 & 17 \\
\hline JJA & 53 & 68 & 58 & 27 & 72 & 72 & 36 & 49 & 56 \\
\hline SON & 14 & 69 & 53 & -42 & -3 & 36 & -24 & 0 & 18 \\
\hline Jan & 18 & 48 & 58 & 30 & - & - & -9 & 18 & -47 \\
\hline Feb & 51 & 52 & 44 & -32 & 47 & 57 & 25 & 20 & 7 \\
\hline Mar & 84 & 17 & 78 & 31 & 32 & 42 & 61 & 21 & 32 \\
\hline Apr & 24 & -10 & 42 & -31 & -26 & 23 & 5 & -18 & 13 \\
\hline May & 43 & 52 & 49 & -77 & 23 & 30 & 45 & 65 & 34 \\
\hline Jun & 44 & 51 & 0 & 7 & -15 & 34 & -13 & 44 & -63 \\
\hline Jul & 37 & 57 & 81 & 29 & 75 & 80 & 27 & 29 & 52 \\
\hline Aug & 22 & -32 & 81 & -33 & 73 & 60 & -10 & 16 & -14 \\
\hline Sep & 7 & 2 & 58 & -40 & 7 & 37 & -6 & -68 & 33 \\
\hline Oct & -12 & -8 & 10 & -29 & 55 & 35 & -24 & 10 & -27 \\
\hline Nov & 71 & 77 & 65 & -27 & - & - & -47 & 16 & -27 \\
\hline Dec & 76 & 70 & 73 & - & - & - & 11 & 34 & -9 \\
\hline
\end{tabular}

gorithm differences instead of differences in the observed radiances (Kahn et al., 2007). More significant differences between AIRS and MODIS retrievals can be found in areas of low clouds in the Arctic in summer (Weisz et al., 2007) as AIRS is less capable to detect the multiple layers summer clouds. However, AIRS is better suited to retrieve thin cirrus than MODIS (e.g. Kahn et al., 2007; Weisz et al., 2007) especially during the polar winter and at night (Kahn et al., 2005). Additionally, AIRS retrieval of cloud top pressure performs better than MODIS retrievals over polar regions, especially in presence of low-level temperature inversions (Weisz et al., 2007).

Figure 6 describes the annual cycle of $\mathrm{CF}$ at the three sites based on monthly mean AIRS CF product for a common period of 11 years (2004-2014). At Sodankylä, the 8month period from May to December shows a cloud cover above $50 \%$, with a maximum in June $(>60 \%)$ and a minimum in March $(<40 \%)$. At Thule, the seasonal variation is even larger, with 4 months $<35 \%$ (January to April) and 4 months $>50 \%$. September has the cloudiest conditions $(>60 \%)$ and April has the clearest $(<30 \%)$. At NyÅlesund, cloud cover is above $44 \%$ all year long, with values $>50 \%$ during 9 months and a relative minimum $(<50 \%)$ during the JJA summer months. In this section we examine the correlation coefficients between monthly TCWV biases and cloud cover with different temporal sampling. We start with the full time series of monthly means, then move on to the annual cycle (averages over all years for each of the 12 calendar months), next the interannual variability cycle by calendar season (DJF, MAM, JJA, SON) and finally the interannual variability by month. Table 3 illustrates the correlations of TCWV biases with AIRS CF, and Table 4 with MODIS CF.

\subsection{GNSS vs. MODIS}

Although this study uses only clear column water vapour observations, the monthly time series of TCWV differences (GNSS-MODIS) show significant correlations with the coincident AIRS (MODIS) CF at Thule and Ny-Ålesund, with $R=39(44)$ and 44(19) \%, respectively (all significant values are given at a significance level $>95 \%$ ), at Sodankylä, a significant correlation of $49 \%$ is found only with MODIS CF (Tables 3,4) which means that the results at this station are more affected by the different overpasses of AIRS CF.

The annual cycle of TCWV biases shows significant correlation with coincident cloud fraction (both MODIS and AIRS) at Thule with $R=68 \%$. Unlike Ny-Ålesund, this different sensitivity is due to the stronger annual cycle of both cloud fractions at Thule in comparison to Ny-Ålesund (see AIRS CF in Fig. 6). Again, at Sodankylä, the correlation is observed only with MODIS CF $(R=70 \%)$.

The interannual variability is generally more dominant at Ny-Ålesund out of winter $(R=58 \%$ in JJA and MAM (AIRS CF), $R=58 \%$ in SON (MODIS CF)), both cloud fractions are significantly correlated with TCWV biases in August and September, while only AIRS (MODIS) CF has 7(4) significant months with $R>58 \%$. 
Table 4. Correlation coefficients (\%) between TCWV biases and coincident cloud cover (MODIS) at Sodankylä (SODA) $\left(67^{\circ} \mathrm{N}, 26^{\circ} \mathrm{E}\right)$, Thule (THUL) $\left(76^{\circ} \mathrm{N}, 69^{\circ} \mathrm{W}\right)$ and Ny- $\AA$ lesund (NYAL) $\left(78^{\circ} \mathrm{N}, 12^{\circ} \mathrm{E}\right)$ for all months, annual cycle and interannual variability (by season and by month). Correlations with significance level $>95 \%$ are in bold. Similar significant correlations to Table 3 are shown in italics.

\begin{tabular}{|c|c|c|c|c|c|c|c|c|c|}
\hline & \multicolumn{3}{|c|}{ MODIS } & \multicolumn{3}{|c|}{ SCIAMACHY } & \multicolumn{3}{|c|}{ AIRS } \\
\hline & SODA & THUL & NYAL & SODA & THUL & NYAL & SODA & THUL & NYAL \\
\hline Monthly & 49 & 44 & 19 & -15 & 58 & 16 & -4 & 41 & 4 \\
\hline An-cycle & 70 & 68 & -11 & -19 & 80 & -48 & -46 & 47 & -22 \\
\hline DJF & 31 & 32 & 25 & -23 & - & - & -2 & 67 & 24 \\
\hline MAM & 45 & 39 & 9 & -10 & 6 & -6 & 20 & 7 & 37 \\
\hline JJA & 56 & 64 & 2 & 22 & 69 & -14 & 44 & 63 & 6 \\
\hline SON & 41 & -2 & 58 & -36 & 5 & 64 & -6 & 2 & -12 \\
\hline Jan & 25 & 2 & 0 & 24 & - & - & 4 & 35 & 53 \\
\hline Feb & 52 & 52 & 5 & -12 & 44 & 75 & 21 & 65 & -34 \\
\hline Mar & 46 & 37 & 12 & 73 & 68 & 47 & 70 & 39 & 26 \\
\hline Apr & 49 & 37 & 57 & -15 & -41 & 49 & 32 & 21 & 29 \\
\hline May & 77 & 40 & 66 & -56 & -4 & 73 & 72 & 37 & -27 \\
\hline Jun & 48 & 19 & 9 & 0 & 34 & 47 & 2 & 18 & -11 \\
\hline Jul & 24 & 81 & 29 & 34 & 20 & -21 & 13 & 89 & -12 \\
\hline Aug & 39 & 66 & 66 & -18 & 51 & 77 & 39 & 20 & -4 \\
\hline Sep & -15 & 10 & 62 & -67 & 3 & -55 & -27 & -54 & 11 \\
\hline Oct & 23 & -5 & 8 & -49 & 42 & 39 & 4 & 26 & 10 \\
\hline Nov & 58 & 21 & 20 & -27 & - & - & -13 & 45 & -46 \\
\hline Dec & 30 & -1 & 43 & - & - & - & 34 & 26 & 4 \\
\hline
\end{tabular}
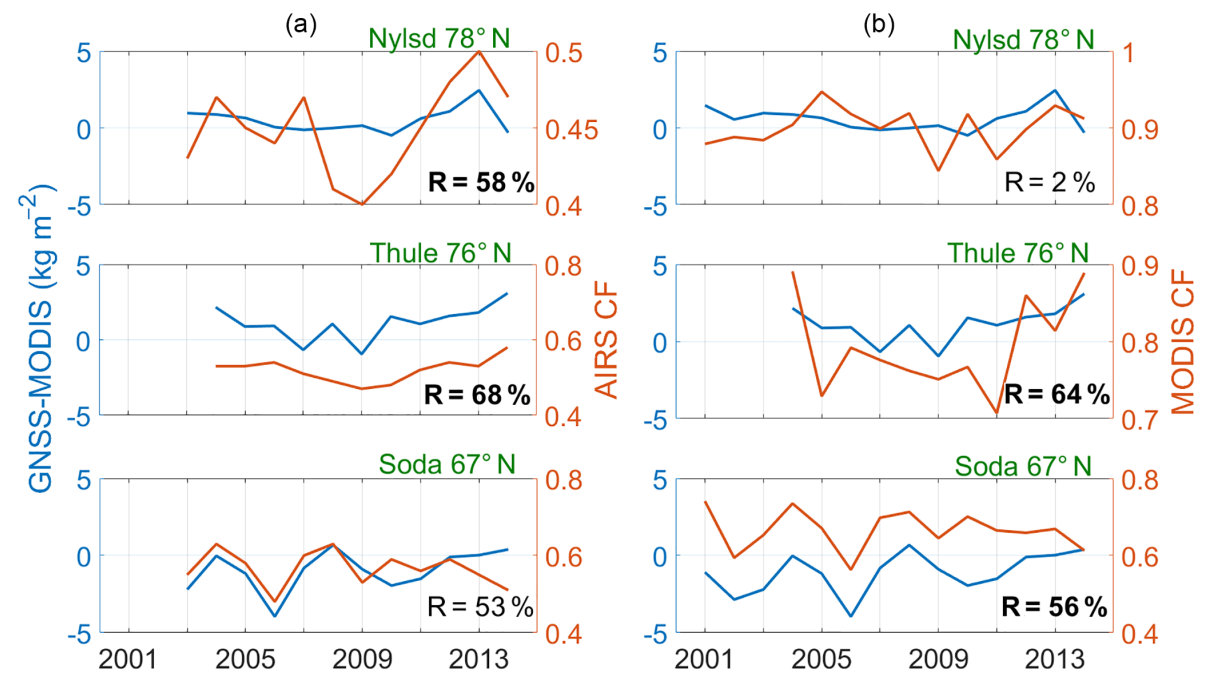

Figure 7. Summer GNSS - MODIS TCWV differences $\left(\mathrm{kg} \mathrm{m}^{-2}\right)$ and AIRS cloud fraction (a) at Ny-Ålesund $\left(78^{\circ} \mathrm{N}, 12^{\circ} \mathrm{E}\right)$, Thule $\left(76^{\circ} \mathrm{N}\right.$, $\left.69^{\circ} \mathrm{W}\right)$ and Sodankylä $\left(67^{\circ} \mathrm{N}, 26^{\circ} \mathrm{E}\right)$ from top to bottom, respectively; (b) is the same but with MODIS cloud fraction. Significant correlations at the $95 \%$ are in bold.

At Thule, the interannual variability is significant with both cloud fractions on summer and additionally on winter and autumn when AIRS CF is used (Table 3). At monthly scale, only 2 months are significant with AIRS CF (November and December with $R=77,70 \%$, respectively), while 2 other months are significant with MODIS CF (July and August with $R=81,66 \%$ ).
The high correlations between TCWV biases and cloud cover in JJA at both sites could explain the poor agreement found in Sect. 3.1 (large biases 0.6 and $1.1 \mathrm{~kg} \mathrm{~m}^{-2}$ and small correlations $R=10$ and $15 \%$; see Table 2) between MODIS and GNSS TCWV time series at Ny-Ålesund and Thule, respectively. Figure 7 gives more insight into the time series at all sites in summer. 
Regarding Sodankylä, TCWV differences show significant correlation with both cloud fractions on November with $R>58 \%$, while only with coincident MODIS CF at monthly $(R=49 \%)$, annual $(R=70 \%)$ and summer interannual variability $(R=56 \%)$. TCWV biases are correlated with AIRS CF during some months of the snow season $(R=76$ and $84 \%$ in December and March, respectively), while with MODIS CF during May $(R=77 \%)$. Consequently, cloud cover may contribute to part of the dry biases in DJF, SON and JJA reported at Sodankylä in Sect. 3.1. However, biases at this site are probably not dominated only by cloud effects. We believe that the environmental features of Sodankylä, which complicate the surface albedo estimation, are also responsible of limiting MODIS retrieval capabilities as previously discussed in Sect. 3.1.

\subsection{GNSS vs. SCIAMACHY}

The monthly time series of SCIAMACHY TCWV biases are significantly correlated at Thule with $R>58 \%$ for both cloud fractions and on the annual scale with $R>75 \%$.

At Ny-Ålesund and Sodankylä, monthly TCWV biases show similar sensitivity to AIRS CF only, with $R=26$ and $29 \%$, respectively.

The correlations at annual scale at Thule and Ny-Ålesund behave again like in Sect. 4.1. They increase at Thule (from $R=60 \%$ (AIRS CF) and $58 \%$ (MODIS CF) at monthly scale to $R=75 \%$ (AIRS CF) and $80 \%$ (MODIS CF) at annual scale) and decrease at Ny-Ålesund (from $R=26 \%$ to $-19 \%$; AIRS CF only), while at Sodankylä the annual variations are strongly correlated (only with AIRS CF) at $R=75 \%$.

SCIAMACHY's TCWV retrieval is more sensitive to cloud cover than MODIS when AIRS CF is used, but MODIS retrieval shows more sensitivity to MODIS CF. Different sensitivity is observed to each of the used cloud fraction products, which is probably linked to closer SCIAMACHY overpasses with AIRS CF than with MODIS CF. The results at Sodankylä are thought to be more influenced by the diurnal variability and thereby the matched passing hours $(\mathrm{CF}$ and satellites). Similar sensitivities to both cloud fractions are marked in red in Table 4.

Generally, our results agree with the findings of Palm et al. (2010) who concluded that cloudy conditions introduce a severe bias at Ny-Ålesund, even if the SCIAMACHY measurement passes the cloud screening filter.

As found with MODIS (Sect. 4.1), TCWV biases and both cloud fractions are strongly correlated at the interannual scale in JJA at Thule with $R>69 \%$ (Table 4).

At Ny-Ålesund, TCWV biases are correlated with both cloud fractions in August, while only with AIRS CF for the whole summer with $R=72 \%$ (Table 3 ). Figure 8 shows the strong interannual variability in JJA at all sites.

At Sodankylä, the interannual variability in TCWV biases and both cloud fractions is significantly correlated in May with $R=-77$ and $-56 \%$ (AIRS CF and MODIS CF, respectively). This anticorrelation is not explained yet.

\subsection{GNSS vs. AIRS}

The results with AIRS are quite different compared to SCIAMACHY and MODIS. Whereas monthly time series of TCWV biases show significant positive correlation with both cloud fractions at Thule $(R=31 \%$ (AIRS CF) and $41 \%$ (MODIS CF)) similar to SCIAMACHY and MODIS (Table 4), the correlation is negative or absent at Ny-Ålesund $(R=-42 \%$ (AIRS CF) and 4\% (MODIS CF)). The negative correlation at Ny-Ålesund is explained by the pronounced but opposite annual variations of the TCWV biases (Fig. 5) and the AIRS cloud cover (Fig. 6) at this site, with an annual correlation of $R=-94 \%$ (Table 3).

Overall, Ny-Ålesund TCWV AIRS biases seasonality is almost linear with negative slope with AIRS CF. Moreover, the interannual variability of TCWV biases and AIRS cloud cover is significant at Ny-Ålesund only for $\operatorname{DJF}(R=-63 \%)$ and a few individual months (Table 3 ). The dominated wet biases in winter (AIRS measurements are bigger than those of GNSS unlike SCIAMACHY and MODIS; see Table 2) are found to be sensitive to AIRS CF (Tables 3 and 4). Winter time series at Thule and Ny-Ålesund are shown in Fig. 9.

As for MODIS (Sect. 4.1) and SCIAMACHY (Sect. 4.2), AIRS summer TCWV biases are also sensitive to MODIS CF at Thule (Table 4),

At Sodankylä, no significant correlations are found for the monthly means and the annual cycle, but at interannual scale in March with AIRS CF $(R>61 \%)$ and in May with MODIS CF $(R=72 \%)$.

Most correlations found are sparse temporally and do not show clear features. This might be due to the fact that AIRS TCWV biases are smaller in magnitude (Table 2) and show a different seasonality compared to MODIS and SCIAMACHY.

\section{Conclusions}

This paper found a general good agreement between satellite TCWV retrievals and coincident measurements from three GPS instruments in the Arctic region. MODIS and SCIAMACHY show overall mean dry biases compared to GPS with some seasonal and latitudinal variation. We generally see better agreement (higher correlation, smaller bias and RMSE) between GNSS and AIRS TCWV time series than between GNSS and MODIS or SCIAMACHY. The seasonal (3-monthly) biases do not exceed $1 \mathrm{~kg} \mathrm{~m}^{-2}$ with AIRS, $2.5 \mathrm{~kg} \mathrm{~m}^{-2}$ with SCIAMACHY (except at Sodankylä for both satellites during summer) and $3.5 \mathrm{~kg} \mathrm{~m}^{-2}$ with MODIS. At Sodankylä, the agreement between GNSS and satellite retrievals is lower for all three satellite measurements. We do not suspect the GNSS data as they passed a selective qual- 

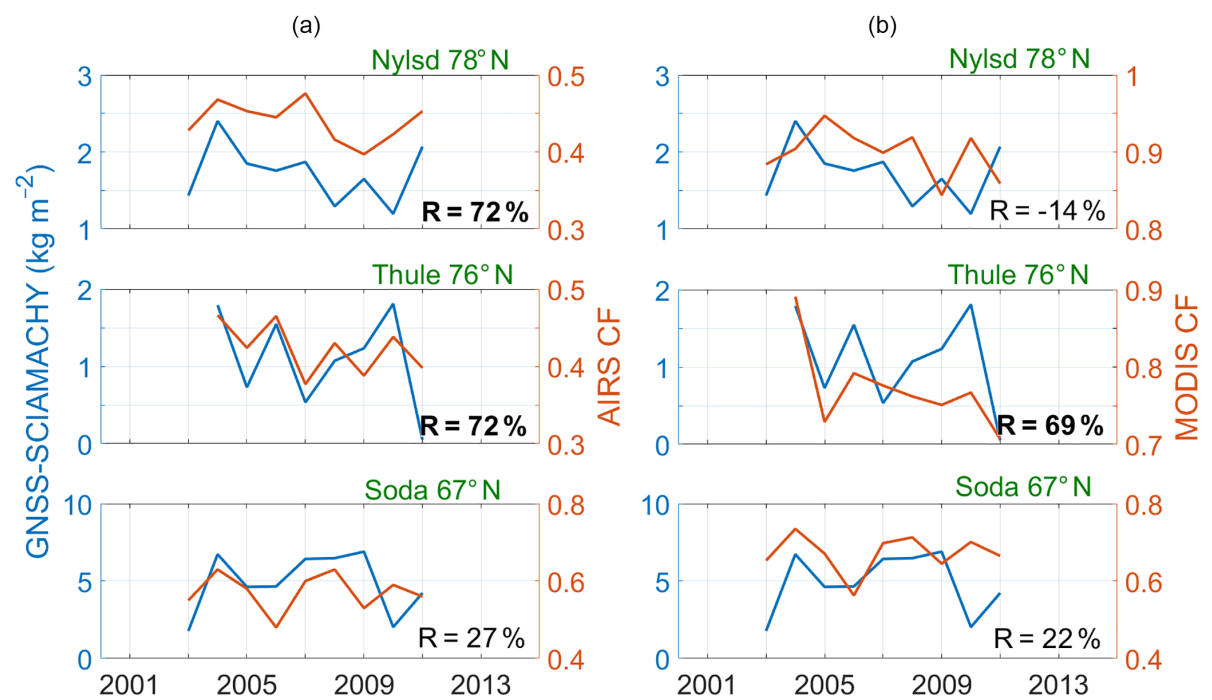

Figure 8. Summer GNSS - SCIAMACHY TCWV differences $\left(\mathrm{kg} \mathrm{m}^{-2}\right)$ and AIRS cloud fraction (a) at Ny-Ålesund (78 $\left.{ }^{\circ} \mathrm{N}, 12^{\circ} \mathrm{E}\right)$, Thule $\left(76^{\circ} \mathrm{N}, 69^{\circ} \mathrm{W}\right)$ and Sodankylä $\left(67^{\circ} \mathrm{N}, 26^{\circ} \mathrm{E}\right)$ from top to bottom, respectively. Panel (b) is the same but with MODIS cloud fraction. Significant correlations at the $95 \%$ are in bold.
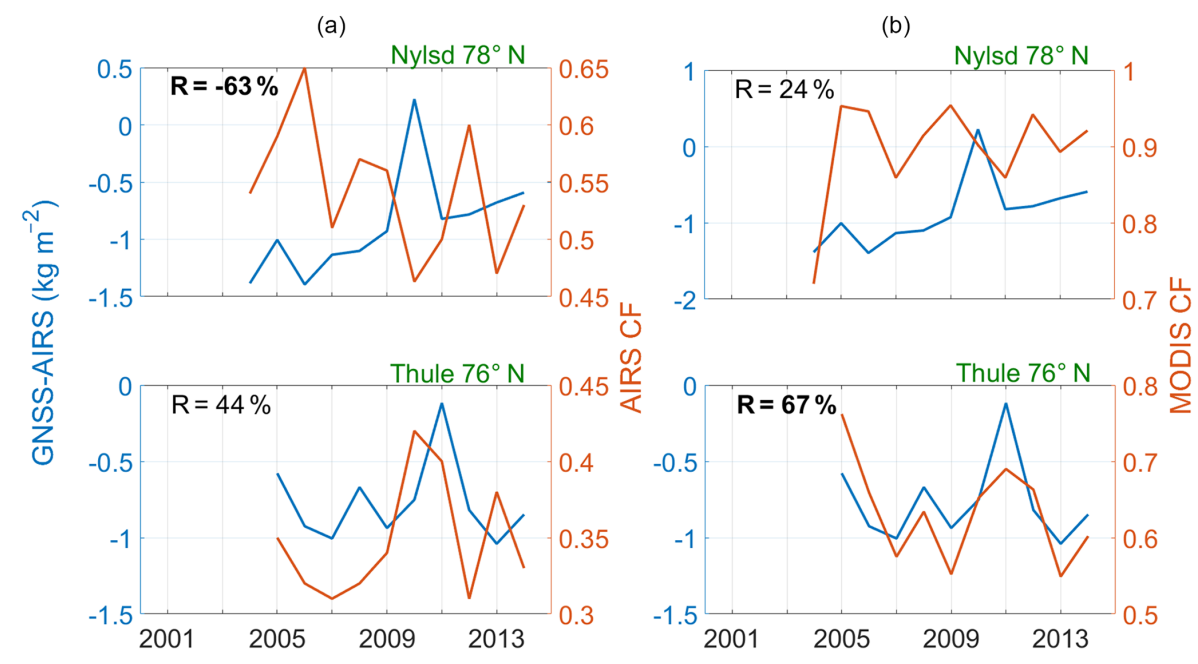

Figure 9. Winter GNSS - AIRS TCWV differences $\left(\mathrm{kg} \mathrm{m}^{-2}\right)$ and AIRS cloud fraction (a) at Ny-Ålesund $\left(78^{\circ} \mathrm{N}, 69^{\circ} \mathrm{W}\right)$ and Thule $\left(76^{\circ} \mathrm{N}\right.$, $69^{\circ} \mathrm{W}$ ) from top to bottom, respectively. Panel (b) is the same but for MODIS cloud fraction. Significant correlations are in bold.

ity control and outlier detection procedure. Instead, we hypothesise that satellite retrievals are impacted by local effects (cloud cover and canopy).

For MODIS, the interannual agreement is getting better with latitude over all seasons except summer. During summer, the interannual variability is actually getting worse at higher-latitude sites. These increased summer biases are found to be sensitive to clouds cover. Additionally, MODIS dry biases during some snowy months at Sodankylä are also correlated with cloud fraction. However, the inaccurate estimation of the surface albedo over a complex mixed surface (snow and nearby canopies) also limits the MODIS retrieval capabilities at Sodankylä.
Summer SCIAMACHY-GNSS TCWV biases are found to be correlated with cloud cover at the higher-latitudes sites (Thule and Ny-Ålesund), in similar way as MODIS ones, but unlike AIRS. However, both MODIS and SCIAMACHY seem to be more sensitive to cloud fraction than AIRS as the annual cycle of TCWV bias for both satellites is well correlated with the annual variations of cloud fraction at Thule and Sodankylä. AIRS time series of TCWV differences to GNSS show a limited link with cloud fraction compared to MODIS and SCIAMACHY (except at Thule) with no clear features. Results reveal anticorrelated monthly differences with AIRS $\mathrm{CF}$ at Ny-Ålesund, probably due to opposite correlation with clouds in winter. Cloud presence is reported to affect satel- 
lite TCWV measurements more clearly at Thule compared to both other sites.

Overall, our results suggest a probable link between satellites TCWV biases to GNSS and cloud cover fraction, with contrasted regional and seasonal features. This sensitivity is strong to both AIRS and MODIS cloud fractions at Thule as both cloud fractions are more correlated at this station, and at all stations during summer. GNSS-AIRS biases are stronger correlated to the AIRS CF than to MODIS CF, whereas GNSS-MODIS biases are stronger correlated to MODIS CF. The use of two cloud fractions clears out a possible influence of the diurnal differences on studying the cloud impact. This effect is decreasing with latitude, as different sensitivity to both cloud fractions is mostly noticed at Sodankylä, which is thought to be linked to the diurnal variability.

We suggest that more robust information on clouds is included in the satellite data processing procedures in order to reduce the TCWV biases in the Arctic and then improve space-borne instrumental uncertainties. We suggest also using GNSS TCWV data in the calibration of satellite TCWV measurements.

Data availability. All TCWV data are publicly available with the exception of the SCIAMACHY data set, which is obtainable by contacting Stephan Noel (data director, cited in the SCIAMACHY data section). All other data (which are cited with DOI and references in the article) are also available via Giovanni (NASA) online application. TCWV data and cloud cover at the three stations for the studied period are included in the Supplement.

Supplement. The supplement related to this article is available online at: https://doi.org/10.5194/amt-11-2949-2018-supplement.

Competing interests. The authors declare that they have no conflict of interest.

Special issue statement. This article is part of the special issue "Advanced Global Navigation Satellite Systems tropospheric products for monitoring severe weather events and climate (GNSS4SWEC) (AMT/ACP/ANGEO inter-journal SI)". It is not associated with a conference.

Acknowledgements. This work was developed in the framework of the VEGA project and supported by the French program LEFE/INSU. This work is a contribution to the European COST Action ES1206 GNSS4SWEC (GNSS for Severe Weather and Climate monitoring; http://www.cost.eu/COST_Actions/essem/ES1206, last access: 15 May 2018) aiming at the development of the global GNSS network for atmospheric research and climate change monitoring. The authors would like to thank Jan Dousa, GOP, Czech Republic, for providing the reprocessed GPS ZTD data, and the staff from the Climserv data centre at IPSL for providing the
ERA-Interim data.

Edited by: Roeland Van Malderen

Reviewed by: two anonymous referees

\section{References}

Ackerman, S. A., Holz, R. E., Frey, R., Eloranta, E. W., Maddux, B. C., and McGill, M.: Cloud detection with MODIS. Part II: validation, J. Atmos. Ocean. Technol., 25, 1073-1086, 2008.

Bevis, M., Businger, S., Herring, T. A., Rocken, C., Anthes, R. A., and Ware, R. H.: GPS Meteorology: Remote Sensing of Atmospheric Water Vapor Using the Global Positioning System, J. Geophys. Res., 97, 15787-15801, 1992.

Bock, O. and Nuret, M.: Verification of NWP Model Analyses and Radiosonde Humidity Data with GPS Precipitable Water Vapor Estimates during AMMA, Weather Forecast., 24, 1085-1101, https://doi.org/10.1175/2009WAF2222239.1, 2009.

Bock, O., Bouin, M. N., Walpersdorf, A., Lafore, J. P., Janicot, S., Guichard, F., and Agusti-Panareda, A.: Comparison of groundbased GPS precipitable water vapour to independent observations and NWP model reanalyses over Africa, Q. J. Roy. Meteor. Soc., 133, 2011-2027, 2007.

Bock, O., Willis, P., Wang, J., and Mears, C.: A high-quality, homogenized, global, long-term (1993-2008) DORIS precipitable water data set for climate monitoring and model verification, J. Geophys. Res. Atmos., 119, 7209-7230, https://doi.org/10.1002/2013JD021124, 2014.

Chahine, M. T.: The hydrological cycle and its influence on climate, Nature, 359, 373-380, https://doi.org/10.1038/359373a0, 1992.

Chen, Y., Miller, J. R., Francis, J. A., and Russell, G. L.: Projected regime shift in Arctic cloud and water vapor feedbacks, Environ. Res. Lett., 6, 44007, https://doi.org/10.1088/17489326/6/4/044007, 2011.

Davis, J. L., Herring, T. A., Shapiro, I. I., Rogers, A. E. E., and Elgered, G.: Geodesy by radio interferometry: Effects of atmospheric modeling errors on estimates of baseline length, Radio Sci., 20, 1593-1607, 1985.

Dee, D. P., Uppala, S. M., Simmons, A. J., Berrisford, P., Poli, P., Kobayashi, S., Andrae, U., Balmaseda, M. A., Balsamo, G., Bauer, P., Bechtold, P., Beljaars, A. C. M., van de Berg, L., Bidlot, J., Bormann, N., Delsol, C., Dragani, R., Fuentes, M., Geer, A. J., Haimberger, L., Healy, S. B., Hersbach, H., Holm, E. V., Isaksen, L., Kallberg, P., Kohler, M., Matricardi, M., McNally, A. P., Monge-Sanz, B. M., Morcrette, J.-J., Park, B.-K., Peubey, C., deRosnay, P., Tavolato, C., Thepaut, J.-N., and Vitart, F.: The ERA-Interim reanalysis: Configuration and performance of the data assimilation system, Q. J. Roy. Meteor. Soc., 137, 553-597, 2011.

Divakarla, M. G., Barnet, C. D., Goldberg, M. D., McMillin, L. M., Maddy, E., Wolf, W., Zhou, L., and Liu, X.: Validation of Atmospheric Infrared Sounder temperature and water vapor retrievals with matched radiosonde measurements and forecasts, J. Geophys. Res.-Atmos., 111, 1-20, https://doi.org/10.1029/2005JD006116, 2006.

Doherty, S. J., Warren, S. G., Grenfell, T. C., Clarke, A. D., and Brandt, R. E.: Light-absorbing impurities in Arctic snow, Atmos. 
Chem. Phys., 10, 11647-11680, https://doi.org/10.5194/acp-1011647-2010, 2010.

Dousa, J., Vaclavovic, P., and Elias, M.: Tropospheric products of the second GOP European GNSS reprocessing (1996-2014), Atmos. Meas. Tech., 10, 3589-3607, https://doi.org/10.5194/amt10-3589-2017, 2017.

Fetzer, E., Mcmillin, L. M., Tobin, D., Aumann, H. H., Gunson, M. R., Mcmillan, W. W., Hagan, D. E., Hofstadter, M. D., Yoe, J., Whiteman, D. N., Barnes, J. E., Bennartz, R., Vömel, H., Walden, V., Newchurch, M., Minnett, P. J., Atlas, R., Schmidlin, F., Olsen, E. T., Goldberg, M. D., Zhou, S., Ding, H., Smith, W. L., and Revercomb, H.: AIRS/AMSU/HSB Validation, IEEE T. Geosci. Remote, 41, 418-431, 2003.

Fetzer, E. J., Lambrigtsen, B. H., Eldering, A., Aumann, H. H., and Chahine, M. T.: Biases in total precipitable water vapor climatologies from Atmospheric Infrared Sounder and Advanced Microwave Scanning Radiometer, J. Geophys. Res.-Atmos., 111, D09S16, https://doi.org/10.1029/2005JD006598, 2006.

Francis, J. and Hunter, E.: Changes in the fabric of the Arctic's greenhouse blanket, Environ. Res. Lett., 2, 45011, https://doi.org/10.1088/1748-9326/2/4/045011, 2007.

Gaffen, D. J.: Temporal inhomogeneities in radiosonde temperature records, J. Geophys. Res. Ser., 99, 3667-3676, 1994.

Gao, B.-C. and Kaufman, Y. J.: Water vapor retrievals using Moderate Resolution Imaging Spectroradiometer (MODIS) near-infrared channels, J. Geophys. Res.-Atmos., 108, D13, https://doi.org/10.1029/2002JD003023, 2003.

Gettelman, A., Fetzer, E. J., Eldering, A., and Irion, F. W.: The global distribution of supersaturation in the upper troposphere from the Atmospheric Infrared Sounder, J. Climate, 19, 60896103, https://doi.org/10.1175/JCLI3955.1, 2006.

Ghatak, D. and Miller, J.: Implications for Arctic amplification of changes in the strength of the water vapor feedback, J. Geophys. Res.-Atmos., 118, 7569-7578, https://doi.org/10.1002/jgrd.50578, 2013.

Gryning, S., Halldin, S., and Lindroth, A.: Area averaging of land surface - atmosphere fluxes in NOPEX?: challenges, results and perspectives, Boreal. Environ. Res., 7, 379-387, 2002.

Guerova, G., Brockmann, E., Schubiger, F., Morland, J., and Mätzler, C.: An Integrated Assessment of Measured and Modeled Integrated Water Vapor in Switzerland for the Period 2001-03, J. Appl. Meteorol., 44, 1033-1044, https://doi.org/10.1175/JAM2255.1, 2005.

Hanesiak, J., Melsness, M., and Raddatz, R.: Observed and modeled growing-season diurnal precipitable water vapor in southcentral Canada, J. Appl. Meteorol. Clim., 49, 2301-2314, https://doi.org/10.1175/2010JAMC2443.1, 2010.

Held, I. M. and Soden, B. J.: Water Vapor Feedback and Global Warming, Annu. Rev. Energ. Env., 25, 441-475, https://doi.org/10.1146/annurev.energy.25.1.441, 2000.

Hubanks, P., King, M., Platnick, S., and Pincus, R.: MODIS Atmosphere L3 Gridded Product Algoritham Theoretical Basis Document, 1-88, available at: http://modis-atmos.gsfc.nasa.gov/ MOD08_M3/atbd.html (last access: 15 May 2018), 2008.

Jones, P. D., Trenberth, K. E., Ambenje, P. G., Bojariu, R., Easterling, D. R., Klein Tank, A. M. G., Parker, D. E., Renwick, J. A., Rahimzadeh, F., Rusticucci, M. M., Soden, B. J., and Zhai, P.-M.: Observations: surface and atmospheric climate change, Clim.
Chang. 2007 Phys. Sci. basis. Contrib. Work. Gr. I to Fourth Assess. Rep. Intergov. Panel Clim. Chang., 235-336, 2007.

Kahn, B. H., Liou, K. N., Lee, S. Y., Fishbein, E. F., DeSouza-Machado, S., Eldering, A., Fetzer, E. J., Hannon, S. E., and Strow, L. L.: Nighttime cirrus detection using Atmospheric Infrared Sounder window channels and total column water vapor, J. Geophys. Res.-Atmos., 110, 1-13, https://doi.org/10.1029/2004JD005430, 2005.

Kahn, B. H., Fishbein, E., Nasiri, S. L., Eldering, A., Fetzer, E. J., Garay, M. J., and Lee, S. Y.: The radiative consistency of Atmospheric Infrared Sounder and Moderate Resolution Imaging Spectroradiometer cloud retrievals, J. Geophys. Res.-Atmos., 112, 1-16, https://doi.org/10.1029/2006JD007486, 2007.

Kahn, B. H., Irion, F. W., Dang, V. T., Manning, E. M., Nasiri, S. L., Naud, C. M., Blaisdell, J. M., Schreier, M. M., Yue, Q., Bowman, K. W., Fetzer, E. J., Hulley, G. C., Liou, K. N., Lubin, D., Ou, S. C., Susskind, J., Takano, Y., Tian, B., and Worden, J. R.: The Atmospheric Infrared Sounder version 6 cloud products, Atmos. Chem. Phys., 14, 399-426, https://doi.org/10.5194/acp-14-3992014, 2014.

Kiehl, J. T. and Trenberth, K. E.: Earth's Annual Global Mean Energy Budget, B. Am. Meteorol. Soc., $\quad 78, \quad 197-208, \quad$ https://doi.org/10.1175/15200477(1997)078<0197:EAGMEB>2.0.CO;2, 1997.

Lambrigtsen, B. H.: AIRS Project Algorithm Theoretical Basis Document Level 1 b Part 3: Microwave Instruments, available at: https://trs.jpl.nasa.gov/bitstream/handle/2014/14259/00-0672. pdf (last access: 15 May 2018), 1999.

Liu, J., Liang, H., Sun, Z., and Zhou, X.: Validation of the Moderate-Resolution Imaging Spectroradiometer precipitable water vapor product using measurements from GPS on the Tibetan Plateau, J. Geophys. Res.-Atmos., 111, 1-5, https://doi.org/10.1029/2005JD007028, 2006.

Lu, N., Qin, J., Yang, K., Gao, Y., Xu, X., and Koike, T.: On the use of GPS measurements for Moderate Resolution Imaging Spectrometer precipitable water vapor evaluation over southern Tibet, J. Geophys. Res.-Atmos., 116, 1-7, https://doi.org/10.1029/2011JD016160, 2011.

Meinander, O., Kazadzis, S., Arola, A., Riihelä, A., Räisänen, P., Kivi, R., Kontu, A., Kouznetsov, R., Sofiev, M., Svensson, J., Suokanerva, H., Aaltonen, V., Manninen, T., Roujean, J.-L., and Hautecoeur, O.: Spectral albedo of seasonal snow during intensive melt period at Sodankylä, beyond the Arctic Circle, Atmos. Chem. Phys., 13, 3793-3810, https://doi.org/10.5194/acp13-3793-2013, 2013.

Miller, J. R., Chen, Y., Russell, G. L., and Francis, J. A.: Future regime shift in feedbacks during Arctic winter, Geophys. Res. Lett., 34, 7-10, https://doi.org/10.1029/2007GL031826, 2007.

Ning, T., Wang, J., Elgered, G., Dick, G., Wickert, J., Bradke, M., Sommer, M., Querel, R., and Smale, D.: The uncertainty of the atmospheric integrated water vapour estimated from GNSS observations, Atmos. Meas. Tech., 9, 79-92, https://doi.org/10.5194/amt-9-79-2016, 2016.

Noël, S.: Description of the AMC-DOAS algorithm, 1-11, available at: http://www.iup.uni-bremen.de/amcdoas/Papers/ AlgorithmDescription.pdf (last access: 15 March 2018), 2007a.

Noël, S.: Product Specification Document for SCIAMACHY water vapour column swath data derived using the AMCDOAS method, technical report, available at: http://www.iup. 
uni-bremen.de/amcdoas/Papers/AlgorithmDescription.pdf (last access: 15 May 2018), 2007b.

Noël, S., Buchwitz, M., and Burrows, J. P.: First retrieval of global water vapour column amounts from SCIAMACHY measurements, Atmos. Chem. Phys., 4, 111-125, https://doi.org/10.5194/acp-4-111-2004, 2004.

Pałm, M., Melsheimer, C., Noël, S., Heise, S., Notholt, J., Burrows, J., and Schrems, O.: Integrated water vapor above $\mathrm{Ny}$ Ålesund, Spitsbergen: a multi-sensor intercomparison, Atmos. Chem. Phys., 10, 1215-1226, https://doi.org/10.5194/acp-101215-2010, 2010.

Piters, A. J. M., Bramstedt, K., Lambert, J.-C., and Kirchhoff, B.: Overview of SCIAMACHY validation: 2002-2004, Atmos. Chem. Phys., 6, 127-148, https://doi.org/10.5194/acp-6-1272006, 2006.

Platnick, S., King, M. D., Ackerman, S. A., Menzel, W. P., Baum, B. A., Riédi, J. C., and Frey, R. A.: The MODIS cloud products: Algorithms and examples from terra, IEEE T. Geosci. Remote, 41, 459-472, https://doi.org/10.1109/TGRS.2002.808301, 2003.

Platnick, S., et al.: MODIS Atmosphere L3 Monthly Product. NASA MODIS Adaptive Processing System, Goddard Space Flight Center, USA, https://doi.org/10.5067/MODIS/MOD08_M3.006, 2015.

Ramanathan, V. and Inamdar, A.: The radiative forcing due to clouds and water vapor, in: Frontiers of Climate Modeling, edited by: Kiehl, J. T. and Ramanathan, V., Cambridge University Press, C Cambridge University Press, available at: http://ruby.fgcu. edu/courses/twimberley/envirophilo/Forcing.pdf (last access: 15 May 2018), 2006.

Rama Varma Raja, M. K., Gutman, S. I., Yoe, J. G., McMillin, L. M., and Zhao, J.: The validation of AIRS retrievals of integrated precipitable water vapor using measurements from a network of ground-based GPS receivers over contiguous United States, J. Atmos. Ocean. Tech., 25, 416-428, https://doi.org/10.1175/2007JTECHA889.1, 2008.

Rangwala, I., Miller, J. R., and Xu, M.: Warming in the Tibetan Plateau: Possible influences of the changes in surface water vapor, Geophys. Res. Lett., 36, 1-6, https://doi.org/10.1029/2009GL037245, 2009.

Ruckstuhl, C., Philipona, R., Morland, J., and Ohmura, A.: Observed relationship between surface specific humidity, integrated water vapor, and longwave downward radiation at different altitudes, J. Geophys. Res., 112, 1-7, https://doi.org/10.1029/2006JD007850, 2007.

Schneider, E. K., Kirtman, B. P., and Lindzen, R. S.: Tropospheric Water Vapor and Climate Sensitivity, J. Atmos. Sci., 56, 1649-1658, https://doi.org/10.1175/15200469(1999)056<1649:TWVACS>2.0.CO;2, 1999.

Schneider, T., O'Gorman, P. A., and Levine, X.: Water vapor and the dynamics of climate changes, Rev. Geophys., 48, 1-22, https://doi.org/10.1029/2009RG000302, 2010.

Screen, J. A. and Simmonds, I.: The central role of diminishing sea ice in recent Arctic temperature amplification, Nature, 464, 1334-1337, https://doi.org/10.1038/nature09051, 2010.

Serreze, M. C., Barrett, A. P., Slater, A. G., Woodgate, R. A., Aagaard, K., Lammers, R. B., Steele, M., Moritz, R., Meredith, M., and Lee, C. M.: The large-scale freshwater cycle of the Arctic, J. Geophys. Res.-Ocean., 111, C11, https://doi.org/10.1029/2005JC003424, 2006.
Sherwood, S. C., Roca, R., Weckwerth, T. M., and Andronova, N. G.: Tropospheric Water Vapor, Convection, and Climate, Rev. Geophys., 48, 1-29, https://doi.org/10.1029/2009RG000301, 2010.

Strow, L. L., Hannon, S. E., De Souza-Machado, S., Motteler, H. E., and Tobin, D.: An Overview of the AIRS Radiative Transfer Model, IEEE T. Geosci. Remote, 41, 303-313, https://doi.org/10.1109/TGRS.2002.808244, 2003.

Strow, L. L., Hannon, S. E., De-Souza Machado, S., Motteler, H. E., and Tobin, D. C.: Validation of the Atmospheric Infrared Sounder radiative transfer algorithm, J. Geophys. Res.-Atmos., 111, D9, https://doi.org/10.1029/2005JD006146, 2006.

Susskind, J., Barnet, C. D., and Blaisdell, J. M.: Retrieval of Atmospheric and Surface Parameters From AIRS/AMSU/HSB Data in the Presence of Clouds, IEEE T. Geosci. Remote, 41, 390-409, 2003.

Susskind, J., Barnet, C. D., Blaisdell, J. M., Iredell, L., Keita, F., Kouvaris, L., Molnar, G., and Chahine, M. T.: Accuracy of Geophysical Parameters Derived from AIRS/AMSU as a Function of Fractional Cloud Cover, J. Geophys. Res., 111, D09S17, available at: https://ntrs.nasa.gov/archive/nasa/ casi.ntrs.nasa.gov/20060022064.pdf (last access: 15 May 2018), 2006.

Susskind, J., Blaisdell, J. M., and Iredell, L.: Improved methodology for surface and atmospheric soundings, error estimates, and quality control procedures: the atmospheric infrared sounder science team version-6 retrieval algorithm, J. Appl. Remote Sens., 8, 84994, https://doi.org/10.1117/1.JRS.8.084994, 2014.

Thomas, I. D., King, M. A., Clarke, P. J., and Penna, N. T.: Precipitable water vapor estimates from homogeneously reprocessed GPS data: An intertechnique comparison in Antarctica, J. Geophys. Res.-Atmos., https://doi.org/10.1029/2010JD013889, 2011.

Tobin, D. C., Revercomb, H. E., Knuteson, R. O., Lesht, B. M., Strow, L. L., Hannon, S. E., Feltz, W. F., Moy, L. A., Fetzer, E. J., and Cress, T. S.: Atmospheric Radiation Measurement site atmospheric state best estimates for Atmospheric Infrared Sounder temperature and water vapor retrieval validation, J. Geophys. Res.-Atmos., 111, 1-18, https://doi.org/10.1029/2005JD006103, 2006.

Trenberth, K. E. and Stepaniak, D. P.: Covariability of Components of Poleward Atmospheric Energy Transports on Seasonal and Interannual Timescales, J. Climate, 16, 3691-3705, https://doi.org/10.1175/15200442(2003)016<3691:COCOPA>2.0.CO;2, 2003.

Trenberth, K. E., Fasullo, J. and Smith, L.: Trends and variability in column-integrated atmospheric water vapor, Clim. Dynam., 24, 741-758, 2005.

Trenberth, K. E., Smith, L., Qian, T., Dai, A., and Fasullo, J.: Estimates of the Global Water Budget and Its Annual Cycle Using Observational and Model Data, J. Hydrometeorol., 8, 758-769, https://doi.org/10.1175/JHM600.1, 2007.

Van Malderen, R., Brenot, H., Pottiaux, E., Beirle, S., Hermans, C., De Mazière, M., Wagner, T., De Backer, H., and Bruyninx, C.: A multi-site intercomparison of integrated water vapour observations for climate change analysis, Atmos. Meas. Tech., 7, 2487-2512, https://doi.org/10.5194/amt-7-2487-2014, 2014.

Vaquero-Martínez, J., Antón, M., Ortiz de Galisteo, J. P., Cachorro, V. E., Costa, M. J., Román, R., and Bennouna, Y. S.: Validation 
of MODIS integrated water vapor product against reference GPS data at the Iberian Peninsula, Int. J. Appl. Earth Obs. Geoinf., 63, 214-221, https://doi.org/10.1016/j.jag.2017.07.008, 2017.

Wagner, T., Beirle, S., and Mies, K.: Description of the MPI-Mainz $\mathrm{H}_{2} \mathrm{O}$ retrieval, available at: http://www.sciamachy.org/products/ H2O/H2Ovc_IUP_AD.pdf (last access: 19 March 2018), 2011.

Wang, J.: Performance of operational radiosonde humidity sensors in direct comparison with a chilled mirror dew-point hygrometer and its climate implication, Geophys. Res. Lett., 30, 10-13, https://doi.org/10.1029/2003GL016985, 2003.

Wang, J. and Zhang, L.: Systematic errors in global radiosonde precipitable water data from comparisons with groud-based GPS measurements, J. Climate, 21, 2218-2238, https://doi.org/10.1175/2007JCLI1944.1, 2008.
Wang, J. and Zhang, L.: Climate applications of a global, 2-hourly atmospheric precipitable water dataset derived from IGS tropospheric products, J. Geodesy, 83, 209-217, https://doi.org/10.1007/s00190-008-0238-5, 2009.

Weisz, E., Li, J., Menzel, W. P., Heidinger, A. K., Kahn, B. H., and Liu, C. Y.: Comparison of AIRS, MODIS, CloudSat and CALIPSO cloud top height retrievals, Geophys. Res. Lett., 34, 1-5, https://doi.org/10.1029/2007GL030676, 2007.

Winton, M.: Amplified Arctic climate change: What does surface albedo feedback have to do with it?, Geophys. Res. Lett., 33, 14, https://doi.org/10.1029/2005GL025244, 2006.

Wu, D. L., Ackerman, S. A., Davies, R., Diner, D. J., Garay, M. J., Kahn, B. H., Maddux, B. C., Moroney, C. M., Stephens, G. L., Veefkind, J. P., and Vaughan, M. A.: Vertical distributions and relationships of cloud occurrence frequency as observed by MISR, AIRS, MODIS, OMI, CALIPSO, and CloudSat, Geophys. Res. Lett., 36, 1-5, https://doi.org/10.1029/2009GL037464, 2009. 